\title{
Novel Mononuclear Divalent Zinc, Cadmium and Mercury Complexes of Tridentate Hydrazone Ended by Thiophene Ring
}

\author{
Rashy Georgy $^{1(\mathbb{D})}$, Mahmoud Nabil ${ }^{1(\mathbb{D})}$, Ola El-Gammal ${ }^{1, *}$ (I) \\ 1 Department of Chemistry, Faculty of Science, Mansoura of Chemistry, Faculty of Science, Mansoura University; \\ rashygeorge85@gmail.com (R.G.); memo.nabil.2017@gmail.com (M.N.); olaelgammal@yahoo.com (O.E-G.); \\ * Correspondence: olaelgammal@yahoo.com;
}

Scopus Author ID 6506882093

Received: 5.01.2021; Revised: 30.03.2021; Accepted: 5.04.2021; Published: 7.05.2021

\begin{abstract}
New hydrazone derivative, namely (Z)-4-((3-cyano-4,6-dimethyl pyridine-2-yl)amino)-N'(thiophen-2-ylmethylene)benzohydrazide $\left(\mathrm{H}_{2} \mathrm{BTH}\right)$ and its mononuclear $\mathrm{Zn}(\mathrm{II}), \mathrm{Cd}(\mathrm{II})$ and $\mathrm{Hg}$ (II) complexes were prepared and characterized by conventional measurements. Infrared spectral data confirmed that the hydrazone coordinates to metal ion as neutral NS or NO. The structure of $\mathrm{Cd}(\mathrm{II})$ complex was further studied by $\mathrm{x}$-ray powder diffraction. The density functional theory (DFT) based quantum chemical calculations were accomplished at B3LYP/6-level of theory andMuilikan atomic charge in a companion with global and local reactivities and various energetic values have been calculated at the selected atoms, and the reactive sites have been assigned on the surface of the molecules through molecular electrostatic potential (MEP) map. TGA and DrTGA were used to establish some compounds' thermal stability, and the kinetic parameters of activation such as $\Delta \mathrm{G}^{*}$, $\Delta \mathrm{H}^{*}$, and $\Delta \mathrm{S}^{*}$ were determined. Moreover, all investigated compounds were screened for antimicrobial and DNA binding activities.
\end{abstract}

Keywords: thiophene hydrazone; ONO dibasic or monobasic; DFT; optical band gap.

(0) 2021 by the authors. This article is an open-access article distributed under the terms and conditions of the Creative Commons Attribution (CC BY) license (https://creativecommons.org/licenses/by/4.0/).

\section{Introduction}

Hydrazones belong to a class of organic compounds that have the structure, $\mathrm{R}_{1} \mathrm{R}_{2} \mathrm{C}=$ $\mathrm{NNH}_{2}$ [1], and were widely studied owing to their ease of preparation and diverse pharmacological potential. Medicinal chemists worldwide carried out immense research on hydrazones and developed agents with better activity and low toxicity profiles. Hydrazones were proved to possess diverse biological and pharmacological properties such as antimicrobial [2], anti-inflammatory, analgesic [3], anti-tubercular, antiviral [4], anticancer, antiplatelet [5], antimalarial [6], anticonvulsant [7], cardioprotective [8], antiprotozoal [9], anti-trypanosomal [10] anti-schistosomiasis [11] and Parkinson's disease [12]. As hydrazones contain $\mathrm{C}=\mathrm{N}$ bond that is conjugated with a lone pair of electrons of the functional nitrogen atom, the hydrazones nitrogen atoms act as a nucleophile, and the carbon atom has both electrophilic and nucleophilic nature [12]. The combination of hydrazones with other functional groups results in compounds with unique physical and chemical character. Furthermore, because the emerging bacterial resistance causes a widespread problem for treating various infections, the search for antimicrobials is a never-ending task. The present work is focused on the preparation and characterization of a novel hydrazone derivative $\left(\mathrm{H}_{2} \mathrm{BTH}\right)$ and its complexes with $\mathrm{Zn}(\mathrm{II})$, $\mathrm{Cd}(\mathrm{II})$, and $\mathrm{Hg}$ (II) ions, also studying the ability of these compounds to inhibit the growth of bacterial and fungal strains as well as DNA binding. 


\section{Materials and Methods}

\subsection{Materials.}

All reagents used were purchased from Fluka, Aldrich-Sigma companies.

\subsection{Instrumentation.}

Thermo-Nicolet IS10 FTIR spectrometer was used for IR spectral measurements (as $\mathrm{KBr}$ disc). Unicam UV-VIS UV2 spectrometer was used to measure the electronic spectra. ${ }^{1} \mathrm{H}$ NMR spectra in d6-DMSO were recorded on a Varian Gemini WM-200 MHz spectrometer. Thermogravimetric analysis performed using an automatic recording Thermo balance, type 951 DuPont; the heating rate of $10{ }^{\circ} \mathrm{C} / \mathrm{min}\left(25-800{ }^{\circ} \mathrm{C}\right)$ in $\mathrm{N}_{2}$. Mass spectrum recorded on Varian Mat 311. Molar conductance $\left(10^{-3} \mathrm{~mol} / \mathrm{l}\right.$ in DMF) was measured on a Tacussel conductivity bridge model CD6NG. The $\mathrm{C}, \mathrm{H}$, and $\mathrm{N}$ contents were determined using a Perkin-Elmer 2400 series II analyzer, while $\mathrm{M}$ and $\mathrm{Cl}$ contents were determined according to the standard method [13].

\subsection{Synthesis of $\mathrm{H}_{2} \mathrm{BTH}$.}

The ligand (Figure 1) was synthesized by the condensation of 1:1 molar amounts of 4((3-cyano-4,6-dimethylpyridin-2-yl)amino)benzohydrazide $(0.28 \mathrm{~g}, 1 \mathrm{mmol})$ with $0.11 \mathrm{ml}$ of thiophene $(1 \mathrm{mmol})$ in $15 \mathrm{ml}$ hot ethanolic solution. The reaction mixture was boiled under reflux for $2 \mathrm{~h}$, where a peage precipitate was formed, was filtered off, recrystallized from ethanol, and finally dried in a vacuum desiccator over anhydrous $\mathrm{CaCl}_{2}$. The purity of the hydrazone, $\mathrm{H}_{2} \mathrm{BTH}$ (Structure I) was checked using TLC, IR, and ${ }^{1} \mathrm{HNMR}$.spectra.<smiles>Cc1cc(C)c(C#N)c(Nc2ccc(C(=O)N/N=C\c3cccs3)cc2)n1</smiles>

Figure 1. Structure of $\mathrm{H}_{2} \mathrm{BTH}$.

\subsection{Preparation of metal complexes.}

Equimolar amounts $(1.0 \mathrm{mmol})$ of the hydrazone, $\mathrm{H}_{2} \mathrm{BTHand}$ metal chloride in hot ethanol were heated under reflux for $5 \mathrm{~h}$. The pale yellow precipitates that formed were filtered off, washed with ethanol, followed by diethyl ether, and dried in a vacuum desiccator over anhydrous $\mathrm{CaCl}_{2}$. The complexes (Figure 2) are stable in air and insoluble in non-polar solvents but soluble in DMF and DMSO solvents and have non-electrolytic nature $\left(4-17 \mathrm{ohm}^{-1} \mathrm{~cm}^{2} \mathrm{~mol}^{-}\right.$ ${ }^{1}$ )[14]. The analytical data are represented in Table 1 . We carried out many attempts to isolate a single crystal but, unfortunately, failed.

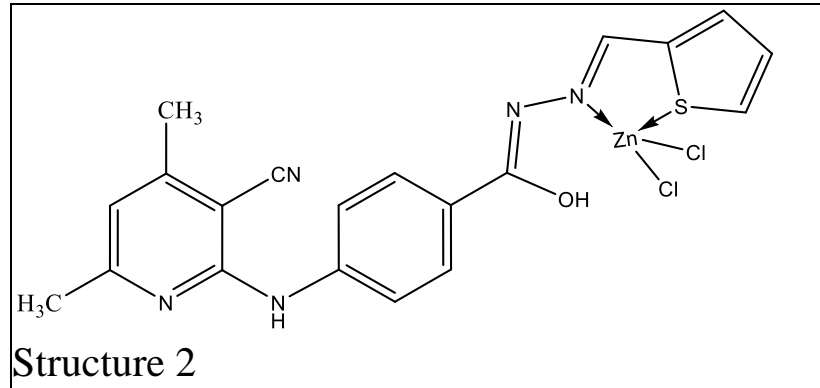




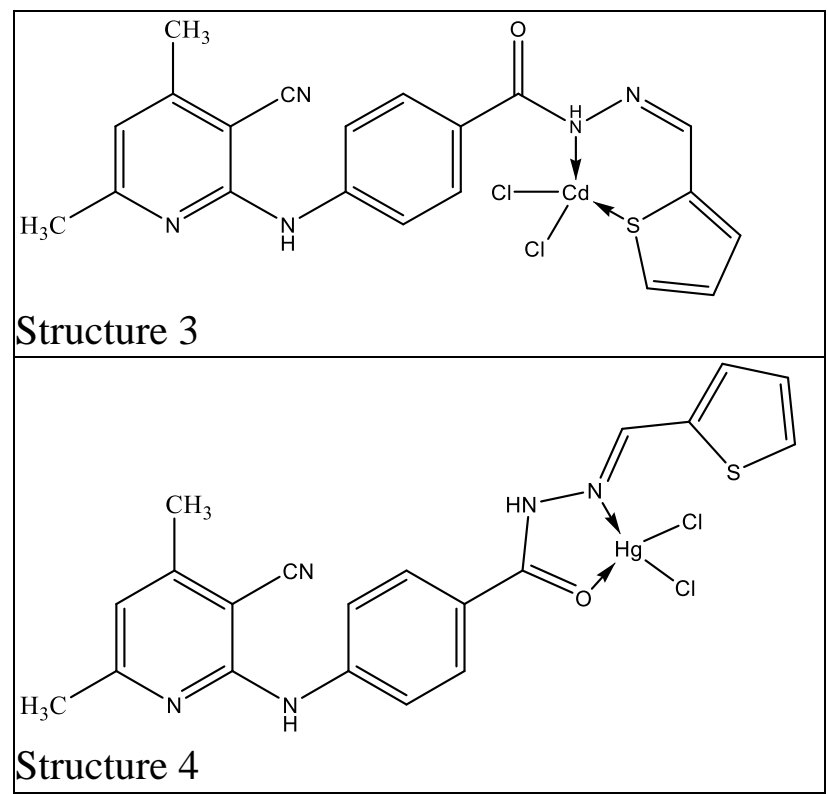

Figure 2. Structures of metal complexes.

Table 1. Physical properties and elemental analyses of $\mathrm{H}_{2} \mathrm{BTH}$ and its metal complexes.

\section{Compound}

(Mol. Wt.)

$\mathrm{H}_{2} \mathrm{BTH}$

$\mathrm{C}_{20} \mathrm{H}_{17} \mathrm{~N}_{5} \mathrm{SO}$

$\left[\mathrm{Zn}\left(\mathrm{H}_{2} \mathrm{BTH}\right) \mathrm{Cl}_{2}\right]$

$\mathrm{C}_{20} \mathrm{H}_{17} \mathrm{Cl}_{2} \mathrm{ZnN}_{5} \mathrm{SO}$

$\left[\mathrm{Cd}\left(\mathrm{H}_{2} \mathrm{BTH}\right) \mathrm{Cl}_{2}\right]$

$\mathrm{C}_{20} \mathrm{H}_{17} \mathrm{Cl}_{2} \mathrm{CdN}_{5} \mathrm{SO}$

[ $\left.\mathrm{Hg}\left(\mathrm{H}_{2} \mathrm{BTH}\right) \mathrm{Cl} 2\right]$

$\mathrm{C}_{20} \mathrm{H}_{17} \mathrm{Cl}_{2} \mathrm{HgN}_{5} \mathrm{SO}$
Color M.P. Found (Calcd.) \%

$\begin{array}{lllllll} & { }^{\mathbf{}} \mathbf{C} & \mathbf{C} & \mathbf{H} & \mathbf{N} & \mathbf{C l} & \mathbf{M} \\ \text { Pale } & 252 & 63.66 & 4.60 & 17.83 & ---- & ---- \\ \text { yellow } & & (63.98) & (4.56) & (18.65) & & \\ \text { Pale } & >300 & 53.24 & 3.51 & 12.28 & 3.27 & 12.83 \\ \text { yellow } & & (53.07) & (3.39) & (11.78) & (7.46) & (13.76) \\ \text { Pale } & >300 & 45.40 & 2.85 & 10.59 & 12.80 & 20.04 \\ \text { yellow } & & (45.18) & (2.88) & (10.03) & (12.70) & (20.13) \\ \text { Pale } & 230 & ---- & ---- & ---- & 11.35 & 31.45 \\ \text { yellow } & & (39.03) & (2.50) & (8.66) & (10.97) & (31.04)\end{array}$

\subsection{Molecular modeling.}

The geometry optimization of the ligand and its metal complexes was carried out using $\mathrm{DMOL}^{3}$ program[15] in the Material studio package for the realization of large-scale density functional theory (DFT) calculations [16]. The DFT semi-core pseudopods calculations (dspp) were performed with the double numerical basis sets plus polarization functional (DNP), which are of comparable quality to 6-31G Gaussian basis sets [17]. Delley et al. showed that the DNP basis sets are more accurate than Gaussian basis sets of the same size [17].

\subsection{Biological studies.}

\subsubsection{Antimicrobial activity.}

The inhibition against bacterial growth was performed towards two bacterial strains (E.coli as a Gram -ve and Staphylococcus aureus as Gram +ve) in addition to one fungus (Candida albicans) by agar well diffusion method [18].DMSO (dimethylsulphoxide) was chosen as a negative control, whereas media with ampicillin (standard antibiotic for bacterial strains) were used as positive control and clotrimazole as a standard antibiotic for fungus strain. The experiments were repeated three times and the values recorded are the mean average. 2.6.2. DNA binding

This assay was displayed using Calf thymus DNA (CT-DNA) as reported [19], where

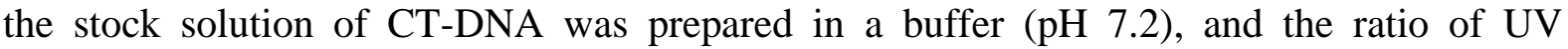
absorbance was determined at 260 and $280 \mathrm{~nm}$ (A260/A280) giving a value of ca. 1.8-1.9, indicating that the DNA was sufficiently free of protein [19], and the concentration was 
determined by UV absorbance at $260 \mathrm{~nm}(\mathcal{E}=6600 \mathrm{Mol}-1 \mathrm{~cm}-1)$. Electronic absorption spectra (200-700 nm) were carried using fixing the ligand or complex concentration with gradual increasing the concentration of CT-DNA (0.00-7.3x 10-6mol L-1). Then an equal amount of CT-DNA was added to both the compound solutions and the references buffer solution to eliminate the absorbance of CT-DNA itself. The intrinsic binding constant $\mathrm{Kb}$ of the compound with CT-DNA was determined using the following Eq. (1):

$$
[D N A] /\left(\varepsilon_{a}-\varepsilon_{f}\right)=[D N A] /\left(\varepsilon_{b}-\varepsilon_{f}\right)+1 / K_{b}\left(\varepsilon_{b}-\varepsilon_{f}\right)(1)
$$

Where [DNA] is the concentration of CT-DNA in base pairs, $\varepsilon_{a}$ is the extinction coefficient observed for the Aobs/[compound] at the given DNA concentration, $\varepsilon_{\mathrm{f}}$ is the extinction coefficient of the free compound in solution, and $\varepsilon_{b}$ is the extinction coefficient of the compound when fully bond to DNA. In plots of [DNA]/( $\left.\mathcal{E}_{\mathrm{a}^{-}} \mathcal{E}_{\mathrm{f}}\right)$ versus [DNA], $\mathrm{K}_{\mathrm{b}}$ is given by the ratio of the slope to the intercept.

\section{Results and Discussion}

\subsection{IR spectra.}

The significant IR bands of $\mathrm{H}_{2} \mathrm{BTH}$ (Structure I) and its metal complexes ( $\mathrm{KBr}$ discs) are listed in Table 2. (Figure 3). The spectrum shows bands at 3333 and $3207 \mathrm{~cm}^{-1}$ assignable to $v(\mathrm{NH})$ attached to pyridine moiety as well as N-H of hydrazone [20]. The band that appeared at $1561 \mathrm{~cm}^{-1}$ is due to $v(\mathrm{C}=\mathrm{N})$ azomethine vibration, while that of medium intensity at $1052 \mathrm{~cm}^{-1}$ is corresponding to $v(\mathrm{~N}-\mathrm{N})$. The bands observed at 1608, 997, 644, and $404 \mathrm{~cm}^{-1}$ are assigned to stretching overlapped with $v(\mathrm{C}=\mathrm{C}) \mathrm{ph}$, pyridine- ring breathing modes, in-plane-bending, and out-of-plane ring vibration modes of $(\mathrm{C}=\mathrm{N})_{\text {pyridine }}$ [21]. The sharp band observed at 2216 and $834 \mathrm{~cm}^{-1}$ may be due to $v(\mathrm{CN})$ in the meta position to $\mathrm{N}$ of pyridine ring and $v(\mathrm{C}-\mathrm{S})$ thio [22] whereas the doublet bands at 2928 and $2963 \mathrm{~cm}^{-1}$ region are assigned to $v_{\text {sy }}$ and $v_{\text {asyvibrations }}$ of methyl groups that are reduced to a weak doublet in metal complexes spectra [23,24].

$\mathrm{H}_{2} \mathrm{BTH}$ chelates as a neutral ligand in the title complexes binding firstly as NS bidentate in $\mathrm{Zn}$ (II) and Cd (II) complexes (Structure $2 \& 3$ ) through $\mathrm{N}$ and $\mathrm{S}$ atoms of $(\mathrm{C}=\mathrm{N})$ azomethine and thiophene ring. The band due to the stretching mode of the carbonyl group is disappeared in the spectrum of the $\mathrm{Zn}$ (II) complex, and instead, a new band appeared at ca. $3400 \mathrm{~cm}^{-1}$ assigned to $v(\mathrm{OH})$, suggesting the conversion $(\mathrm{C}=\mathrm{O} \rightarrow \mathrm{C}-\mathrm{OH})$ and not involved in coordination while in $\mathrm{Cd}(\mathrm{II})$ complex remains at the same position. Secondly, in $\mathrm{Hg}$ (II) complex (Structure 4), the ligand chelates as NO bidentate via $(\mathrm{C}=\mathrm{O})$ and $(\mathrm{C}=\mathrm{N})_{\text {azomethine groups. These chelation modes }}$ are confirmed as follows:

i) The bands due to $v(\mathrm{C}=\mathrm{N})$ azomethine and $v(\mathrm{C}=\mathrm{O})$ shifted to lower wavenumber in $\mathrm{Hg}(\mathrm{II})$ complex as a result of coordination.

ii) The $v(\mathrm{~N}-\mathrm{N})$ shifted to lower wavenumber, which may enhance the double bond character offsetting the loss of electron density by donation to the metal ion and is an additional support of coordination via the $\mathrm{N}$ of azomethine group.

iii) The new bands at 556 and 470-486 $\mathrm{cm}^{-1}$ attributable to $v(\mathrm{M}-\mathrm{O})$ in and $v(\mathrm{M}-\mathrm{N})$ confirm the proposed chelation mode [25]. 
(a)

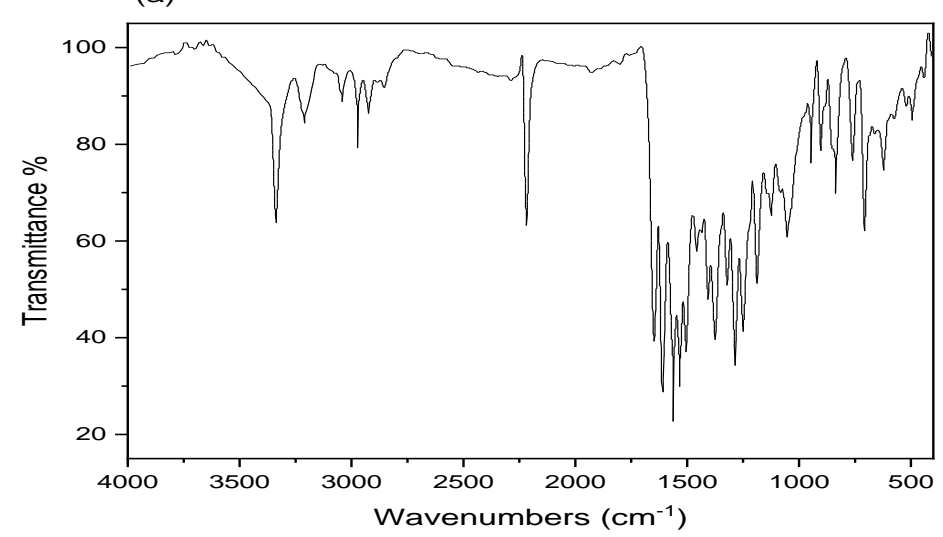

(b)

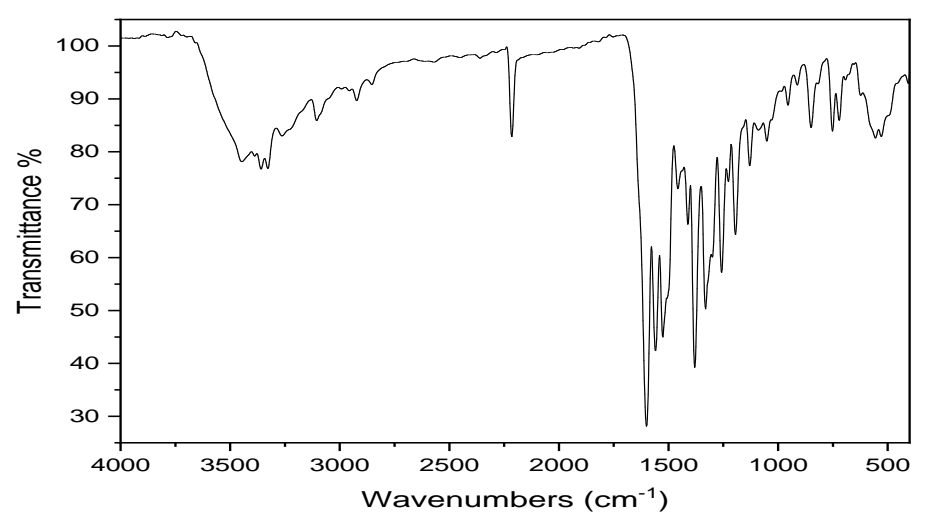

(c)

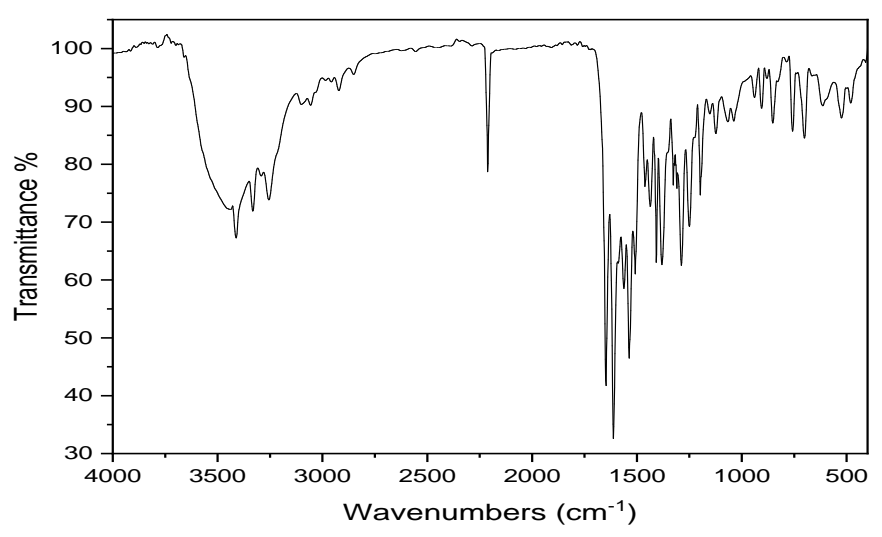

(d)

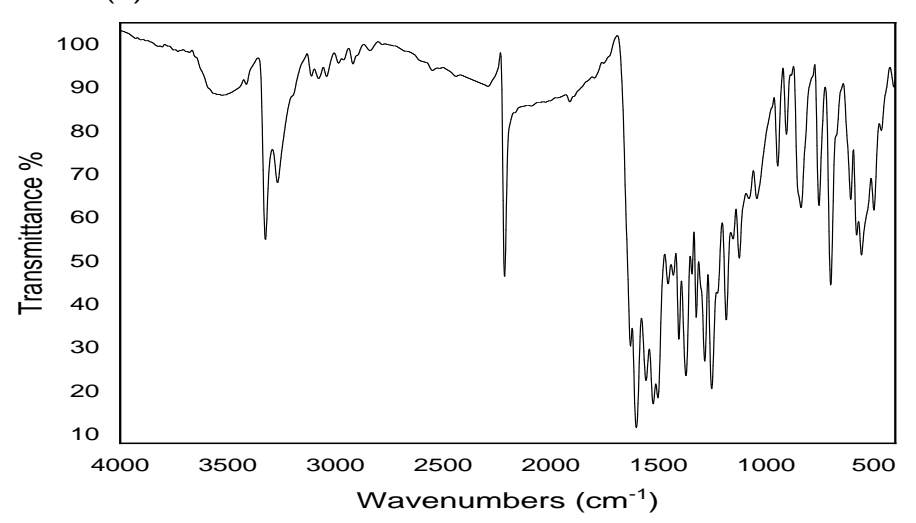

Figure 3. IR spectrum of (a) $\mathrm{H}_{2} \mathrm{BTH}$; (b) $\left[\mathrm{Zn}\left(\mathrm{H}_{2} \mathrm{BTH}\right) \mathrm{Cl}_{2}\right]$, (c) $\left[\mathrm{Cd}\left(\mathrm{H}_{2} \mathrm{BTH}\right) \mathrm{Cl}_{2}\right]$; (d) $\left[\mathrm{Hg}\left(\mathrm{H}_{2} \mathrm{BTH}\right) \mathrm{Cl}_{2}\right]$. 
Table 2. Selected IR spectral data of $\mathrm{H}_{2} \mathrm{BTH}$ and its complexes.

\begin{tabular}{c|c|c|c|c} 
mode & $\mathbf{H}_{2} \mathbf{B} \mathbf{T H}$ & {$\left[\mathbf{Z n}\left(\mathbf{H}_{2} \mathbf{B} \mathbf{T H}\right) \mathbf{C l}_{2}\right]$} & {$\left[\mathbf{C d}\left(\mathbf{H}_{\mathbf{2}} \mathbf{B} \mathbf{T H}\right) \mathbf{C l}_{2}\right]$} & {$\left[\mathbf{H g}\left(\mathbf{H}_{2} \mathbf{B} \mathbf{T H}\right) \mathbf{C l}_{2}\right]$} \\
\hline$v(\mathrm{C}=\mathrm{O})$ & 1646 & ------ & 1648 & 1630 \\
\hline$v(\mathrm{C}=\mathrm{N})$ & 1561 & 1526 & 1562 & 1524 \\
\hline$v(\mathrm{C}=\mathrm{N})_{\mathrm{py}}$ & 1608 & 1600 & 1612 & 1603 \\
\hline$v(\mathrm{NH})_{1}$ & 3335 & 3359 & 3332 & 3326 \\
\hline$v(\mathrm{NH})_{2}$ & 3207 & 3210 & 3256 & 3269 \\
\hline$v(\mathrm{CN})$ & 2216 & 2215 & 2211 & 2215 \\
\hline$v(\mathrm{CS})$ & 834 & 850 & 852 & 838 \\
\hline$v(\mathrm{C}=\mathrm{N})^{*}$ & ----- & 1559 & ----- & ---- \\
\hline$v(\mathrm{~N}=\mathrm{N})$ & 1052 & 1051 & 1066 & 1043 \\
\hline$v(\mathrm{C}-\mathrm{O})^{*}$ & ----- & 1129 & ----- & ----- \\
\hline$v(\mathrm{M}-\mathrm{O})$ & ----- & 556 & ----- & 486
\end{tabular}

\section{2. ${ }^{1} H$ NMR study.}

The data obtained from ${ }^{1}$ HNMR spectra of the ligand and its metal complexes in $\mathrm{d}_{6} \mathrm{DMSO}$ are represented in Table 3 and Figure 4. The ligand spectrum revealed a singlet at $\delta$ $=11.69 \mathrm{ppm}$ due to $(\mathrm{NH})$ proton of hydrazine moiety. The signals at $\delta=7.45,7.13,7.65 \mathrm{ppm}$ (dtd, $3 \mathrm{H}, 4 \mathrm{H}, 5 \mathrm{H})$ of thiophene ring). The signals at $\delta=8.64 \mathrm{ppm}(\mathrm{s}, 1 \mathrm{H}$, azomethine); $\delta=$ $7.73,7.82 \mathrm{ppm}(\mathrm{dd}, 2,6 \mathrm{H}, 3,5 \mathrm{H}$, benzene ring) are observed. The singlet at $\delta=9.28 \mathrm{ppm}$ is due to the amine group attached to the pyridine ring. The signals at $\delta=2.38,2.49 \mathrm{ppm}$ are assigned to aliphatic (two $\mathrm{CH}_{3}$ protons) attached to pyridine moiety (s, $2 \mathrm{CH} 3$ group), and the signal that appeared at $\delta=6.85 \mathrm{ppm}$ is due to $\mathrm{CH}$ proton $(\mathrm{s}, 5 \mathrm{H})$ [26]. The absence of any peaks in the downfield region assignable to the proton of $\mathrm{OH}$ group confirms that the ligand is in the keto form.

On the other hand, the disappearance of the signal observed in the ligand spectrum at $11.69 \mathrm{ppm}$ assignable to the proton of $(\mathrm{NH})$ of hydrazone in the spectrum of $\left[\mathrm{Zn}\left(\mathrm{H}_{2} \mathrm{BTH}\right) \mathrm{Cl}_{2}\right]$ complex as a representative example and appearance of a new one at $12.00 \mathrm{ppm}$ is the support of a change of $\mathrm{C}=\mathrm{O}$ into $\mathrm{C}-\mathrm{OH}$ without participation in bonding. The slight shift of the signal due to azomethine proton confirms the sharing of azomethine nitrogen in coordination with the metal ion.

(a)

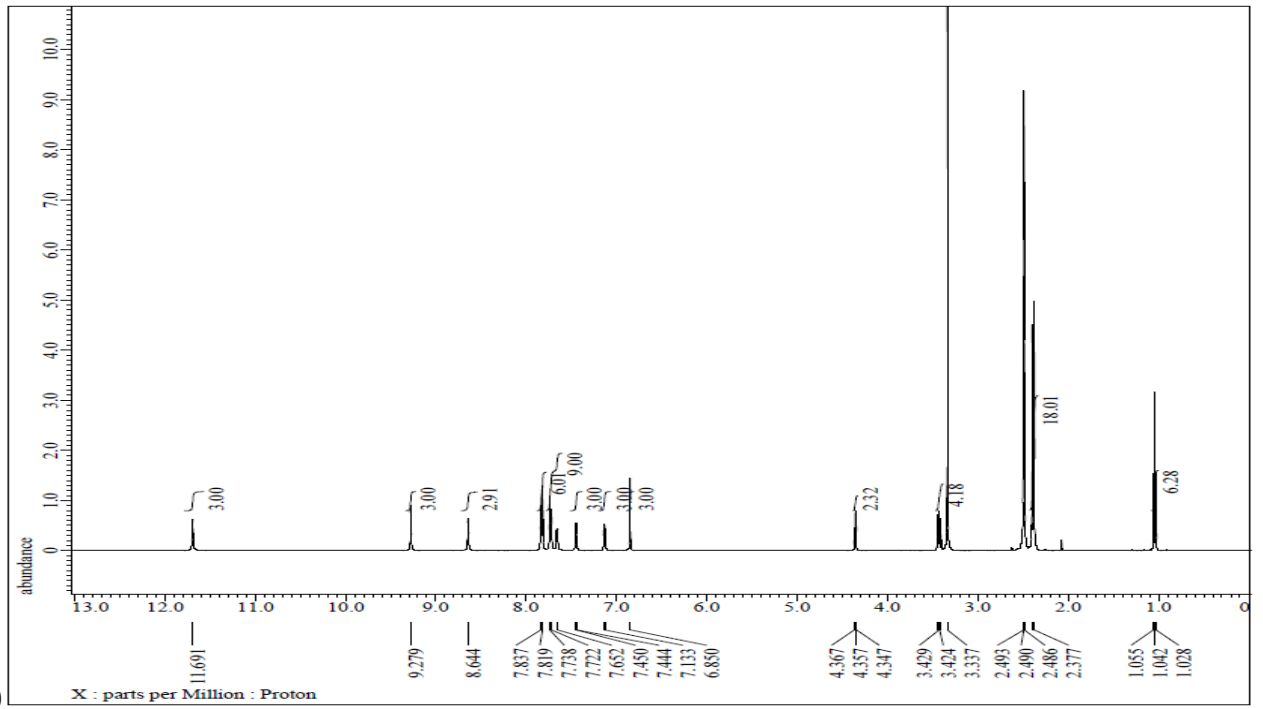


(b)

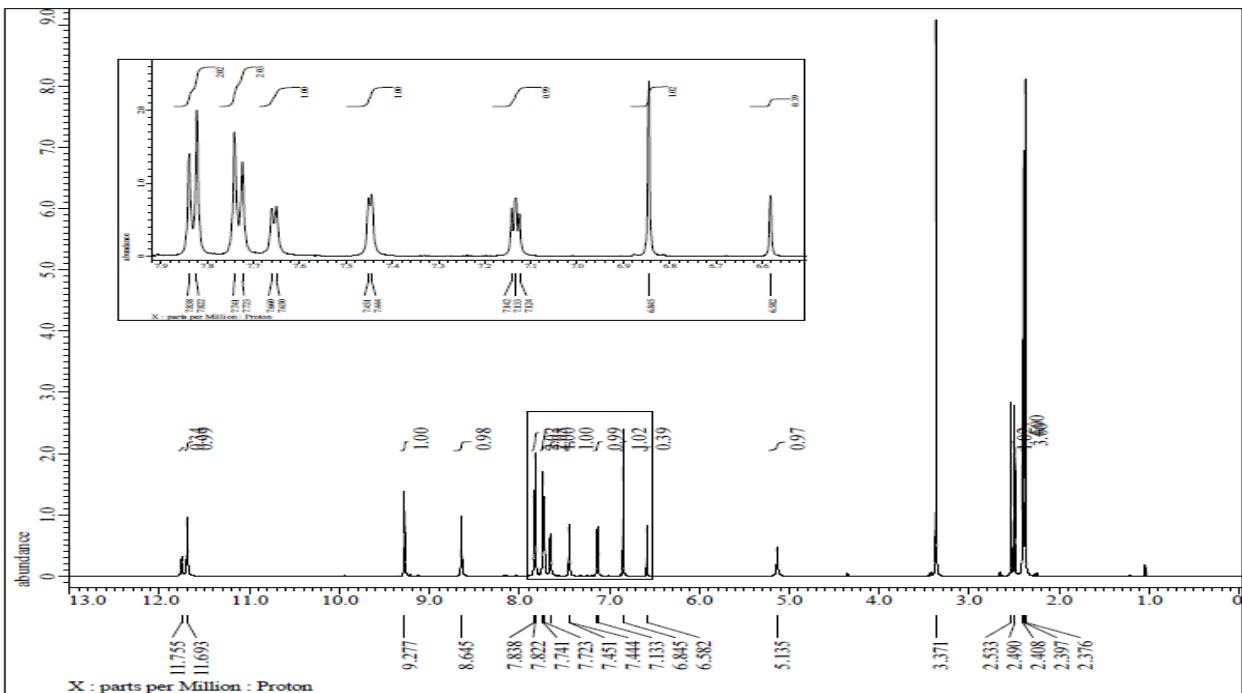

Figure 4. ${ }^{1} \mathrm{HNMR}$ spectra of (a) $\mathrm{H}_{2} \mathrm{BTH}$; (b) $\left[\mathrm{Zn}\left(\mathrm{H}_{2} \mathrm{BTH}\right) \mathrm{Cl}_{2}\right]$ in $\mathrm{d}_{6} \mathrm{DMSO}$.

Table 3. NMR spectral data for $\mathrm{H}_{2} \mathrm{BTH}$ and its complexes.

\begin{tabular}{|c|c|c|c|c|}
\hline Signal Compound. & $\mathrm{H}_{2} \mathrm{BTH}$ & {$\left[\mathrm{Zn}\left(\mathrm{H}_{2} \mathbf{B T H}\right) \mathrm{Cl}_{2}\right]$} & {$\left[\mathrm{Cd}\left(\mathrm{H}_{2} \mathrm{BTH}\right) \mathrm{Cl}_{2}\right]$} & {$\left[\mathrm{Hg}\left(\mathrm{H}_{2} \mathrm{BTH}\right) \mathrm{Cl}_{2}\right]$} \\
\hline$(\mathrm{s}, \mathrm{NH})_{\text {hydrazine }}$ & 11.69 & --- & 11.69 & 11.70 \\
\hline$(\mathrm{dtd}, 3 \mathrm{H}, 4 \mathrm{H}, 5 \mathrm{H})_{\text {thiophene ring }}$ & $7.45,7.13,7.65$ & $7.44,7.13,7.65$ & $7.44,7.13,7.65$ & $7.45,7.13,7.65$ \\
\hline$(\mathrm{s}, 1 \mathrm{H})_{\text {azomethine }}$ & 8.64 & 8.71 & 8.64 & 8.68 \\
\hline$(\mathrm{dd}, 2,6 \mathrm{H}, 3,5 \mathrm{H})$ benzene ring & $7.73,7.82$ & $7.73,7.83$ & $7.72,7.82$ & $7.73,7.82$ \\
\hline$(\mathrm{s}, \mathrm{NH})$ attached to pyridine ring & 9.28 & 9.28 & 9.27 & 9.27 \\
\hline$\left(\mathrm{s}, 2 \mathrm{CH}_{3}\right.$ group $),(\mathrm{s}, 5 \mathrm{H})$ pyridine ring & $2.38,2.49,6.85$ & $2.38,2.40,6.84$ & $2.39,2.41,6.84$ & $2.37,2.39,6.84$ \\
\hline
\end{tabular}

\subsection{UV-visible spectra.}

The spectrum of the investigated hydrazone, $\mathrm{H}_{2} \mathrm{BTH}$ in DMSO (Figure 5), was displayed and exhibited two intense bands at 37037 and $29239 \mathrm{~cm}^{-1}$ attributed to $\pi \rightarrow \pi^{*}$ and $\mathrm{n}$ $\rightarrow \pi^{*}$ transitions due to those of carbonyl and azomethine groups [28].

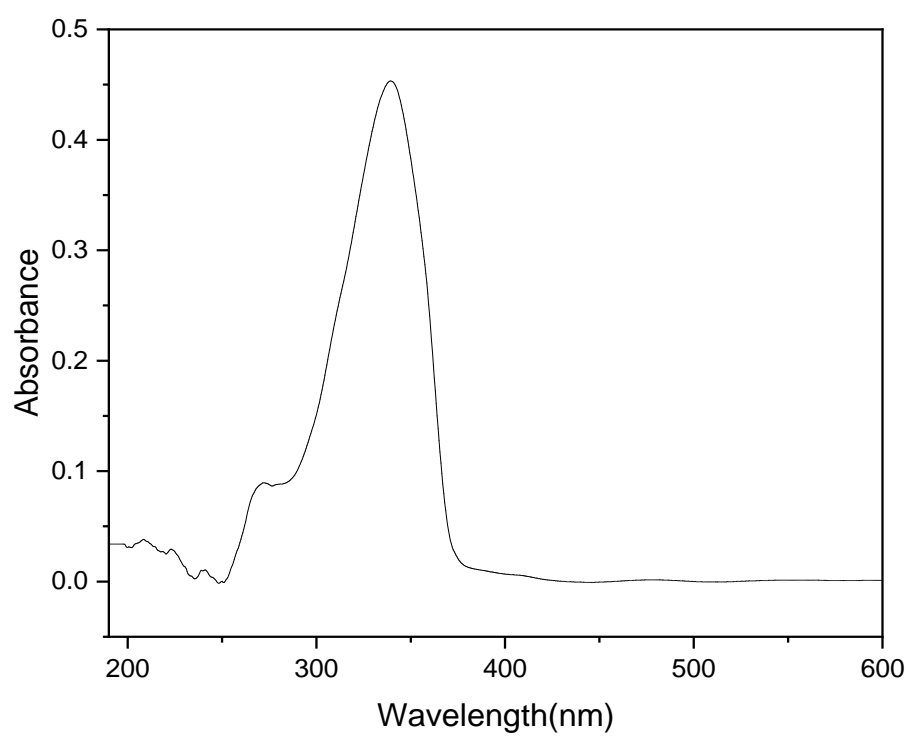

Figure 5. UV-vis. spectrum of $\mathrm{H}_{2} \mathrm{BTH}$.

\subsection{X-ray diffraction.}

The XRD pattern of $\left[\mathrm{Cd}\left(\mathrm{H}_{2} \mathrm{BTH}\right) \mathrm{Cl}_{2}\right]$ complex is depicted in Figure 6 and Table 4. All peaks of diffraction were indexed well into the orthorhombic $\mathrm{C}_{36} \mathrm{H}_{46} \mathrm{CdCl}_{2} \mathrm{~N}_{4} \mathrm{~S}_{4}$ structure with lattice constants: $a=17.488 \AA ; b=22.2870 \AA ; c=22.8110 \AA \mathrm{I} / \mathrm{Ic} 1.05$ and $\alpha=\gamma=90 \& \beta=111.770$ ${ }^{\circ}$ and Pbca space group [29] which is in good agreement with the Joint Committee Powder 


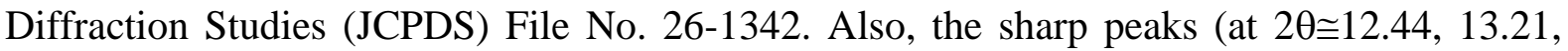
$15.48,26.7329 .16,30.80$ and, $36.78^{\circ}$ ) are appeared in the XRD spectrum are referred to nature of $\mathrm{H}_{2} \mathrm{BTH}$ structure indicating that the free ligand in the $\mathrm{Cd}^{2+}$ complex presented as semicrystalline form [29].

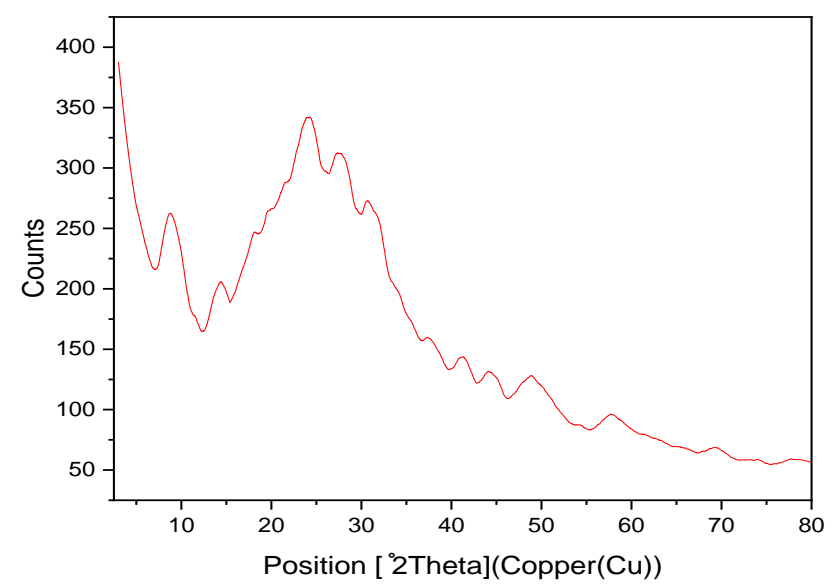

Figure 6. Powder $\mathrm{XRD}$ of $\left[\mathrm{Cd}\left(\mathrm{H}_{2} \mathrm{BTH}\right) \mathrm{Cl}_{2}\right]$.

Table 4. Powder XRD data: FWHM, crystallite (grain) size D, d-spacing, $\varepsilon$ microstrain, and d dislocation density of $\left[\mathrm{Cd}\left(\mathrm{H}_{2} \mathrm{BTH}\right) \mathrm{Cl}_{2}\right]$ complex.

\begin{tabular}{|c|c|c|c|c|c|c|c|}
\hline 2theta $\left[{ }^{\circ}\right]$ & hkl & FWHM [ $\left.{ }^{\circ}\right]$ & $\mathbf{d}[\AA ̊]$ & $\begin{array}{c}\text { Grain Cystallite } \\
\text { size D }(\mathbf{n m})\end{array}$ & $\begin{array}{c}\text { Lattice } \\
\text { strain } \& \times 10^{-3}\end{array}$ & 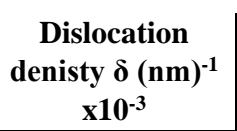 & $\begin{array}{l}\text { Average inner } \\
\text { crystal } \\
\text { separation }(\mathrm{S})\end{array}$ \\
\hline 7.89 & $0,2,0$ & 0.32 & 11.20 & 25.99 & 20.20 & 1.48 & 13.99 \\
\hline 9.31 & $1,0,2$ & 0.52 & 9.49 & 16.01 & 27.90 & 3.90 & 11.86 \\
\hline 11.43 & $2,1,1$ & 0.6 & 7.74 & 13.90 & 26.20 & 5.18 & 9.67 \\
\hline 12.84 & $2,2,0$ & 0.28 & 6.89 & 29.82 & 10.90 & 1.12 & 8.61 \\
\hline 14.05 & $0,2,3$ & 0.88 & 6.30 & 9.50 & 31.20 & 11.10 & 7.87 \\
\hline 17.23 & $1,4,1$ & 0.32 & 5.14 & 26.23 & 9.22 & 1.45 & 6.43 \\
\hline 18.9 & $2,4,0$ & 0.56 & 4.69 & 15.02 & 14.70 & 4.43 & 5.86 \\
\hline 19.23 & $2,4,1$ & 0.56 & 4.61 & 15.03 & 14.40 & 4.43 & 5.76 \\
\hline 21.74 & $4,0,2$ & 0.28 & 4.08 & 30.17 & 6.36 & 1.10 & 5.10 \\
\hline 26.91 & $4,2,4$ & 0.32 & 3.31 & 26.66 & 5.84 & 1.41 & 4.14 \\
\hline 27.3 & $2,5,4$ & 0.32 & 3.26 & 26.68 & 5.75 & 1.40 & 4.08 \\
\hline 27.71 & $3,5,3$ & 0.4 & 3.22 & 21.37 & 7.08 & 2.19 & 4.02 \\
\hline 31.26 & $1,5,6$ & 0.52 & 2.86 & 16.57 & 8.11 & 3.64 & 3.57 \\
\hline 33.28 & $2,1,8$ & 0.24 & 2.69 & 36.08 & 3.50 & 0.77 & 3.36 \\
\hline 41.08 & $6,6,3$ & 0.68 & 2.20 & 13.03 & 7.92 & 5.89 & 2.74 \\
\hline Average & & 0.45 & 5.18 & 21.47 & 13.30 & 3.30 & 6.47 \\
\hline
\end{tabular}

\subsection{Thermogravimetric studies.}

Table 5 listed all data concerning the degradation steps, temperature range, the fragment lost, and the percentage of weight loss for zinc and cadmium complexes. Thermogravimetric curves are represented in Figure 7. The experimental data are in good agreement with the theoretical values with metal oxide as a residual part. 

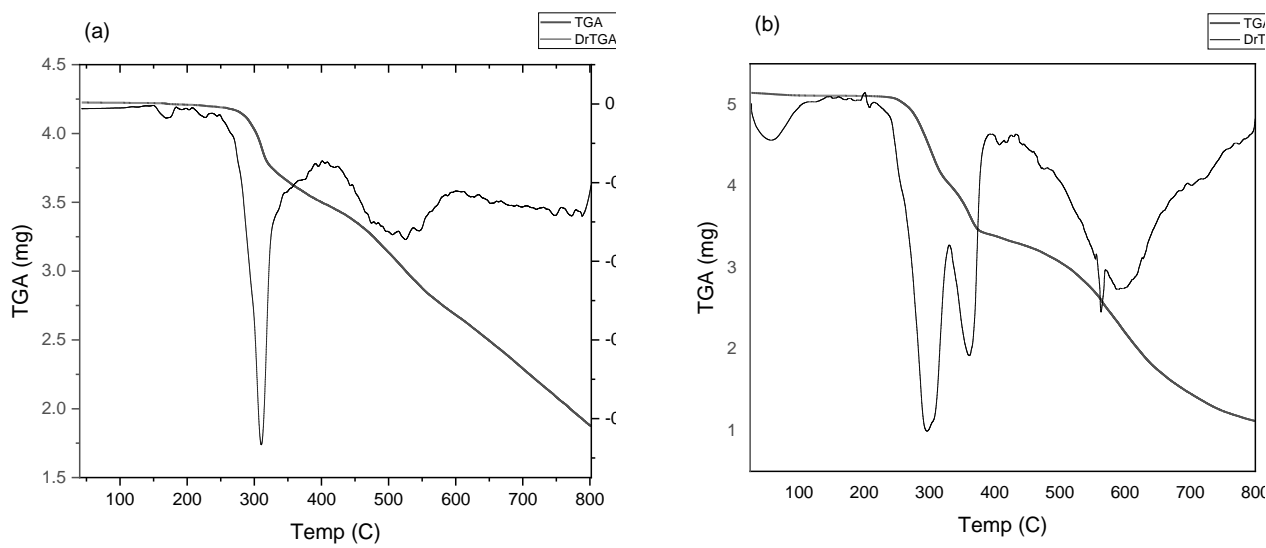

Figure 7. TGA curves of: (a) $\left[\mathrm{Zn}\left(\mathrm{H}_{2} \mathrm{BTH}\right) \mathrm{Cl}_{2}\right]$,(b) $\left[\mathrm{Cd}\left(\mathrm{H}_{2} \mathrm{BTH}\right) \mathrm{Cl}_{2}\right]$.

Table 5. Steps of decomposition with temperature range and weight loss for $\mathrm{H}_{2} \mathrm{BTHand}$ its complexes.

\begin{tabular}{|c|c|c|c|c|c|}
\hline \multirow{2}{*}{ Compound } & \multirow{2}{*}{ Step } & \multirow{2}{*}{$\begin{array}{c}\text { Temp. Range, } \\
{ }^{\circ} \mathrm{C}\end{array}$} & \multirow{2}{*}{ Removed species } & \multicolumn{2}{|c|}{ Wt. Loss (mg) } \\
\hline & & & & Found\% & Calcd\% \\
\hline \multirow{4}{*}[\mathrm{Zn}(\mathrm{H}_{2}\mathrm{BTH})\mathrm{Cl}_{2}]{} & $1 \mathrm{st}$ & $235-408$ & $-2 \mathrm{HCl}+\mathrm{C}_{2} \mathrm{~N}_{2}$ & 24.42 & 1.82 \\
\hline & 2nd & $409-594$ & $\mathrm{C}_{4} \mathrm{H}_{3} \mathrm{~S}$ & 16.43 & 24.71 \\
\hline & $3 \mathrm{rd}$ & $595-752$ & $-\mathrm{C}_{14} \mathrm{H}_{12} \mathrm{~N}_{3}$ & 43.44 & 61.59 \\
\hline & Residue & 800 & $\mathrm{ZnO}$ (Residue) & 15.9 & 11.89 \\
\hline \multirow{4}{*}[\mathrm{Cd}(\mathrm{H}_{2}\mathrm{BTH})\mathrm{Cl}_{2}]{} & $1 \mathrm{st}$ & $219-338$ & $-2 \mathrm{HCl}+\mathrm{C}_{2} \mathrm{~N}_{2}$ & 22.33 & 22.31 \\
\hline & 2nd & $339-475$ & $\mathrm{C}_{4} \mathrm{H}_{3} \mathrm{~S}$ & 14.88 & 15.14 \\
\hline & $3 \mathrm{rd}$ & $476-695$ & $-\mathrm{C}_{14} \mathrm{H}_{12} \mathrm{~N}_{3}$ & 39.81 & 39.65 \\
\hline & Residue & 800 & CdO (Residue) & 22.99 & 22.90 \\
\hline
\end{tabular}
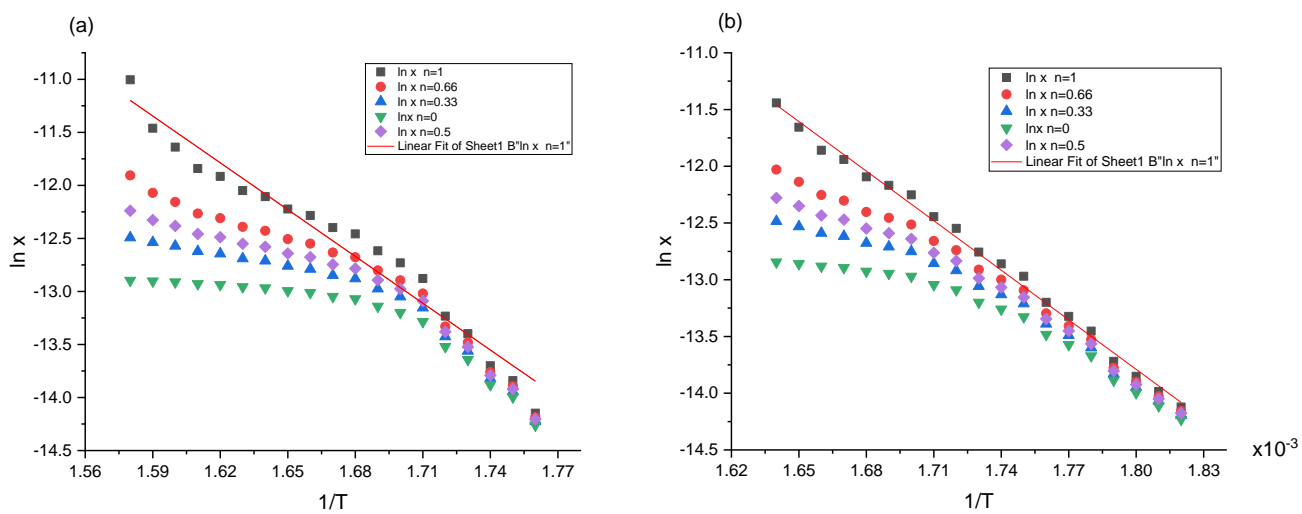

Figure 8. Plots of Coats-Redfern first degradation step for:(a) $\left[\mathrm{Zn}\left(\mathrm{H}_{2} \mathrm{BTH}\right) \mathrm{Cl}_{2}\right]$ and (b) $\left[\mathrm{Cd}\left(\mathrm{H}_{2} \mathrm{BTH}\right) \mathrm{Cl}_{2}\right]$.
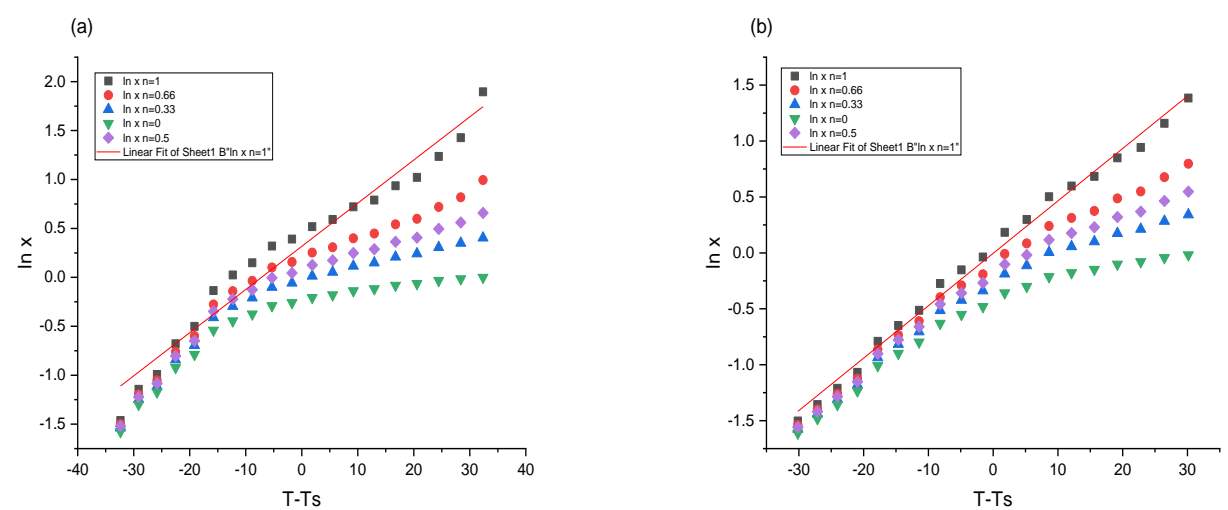

Figure 9. Plots of Horowitz-Metzger first degradation step for:(a) $\left[\mathrm{Zn}\left(\mathrm{H}_{2} \mathrm{BTH}\right) \mathrm{Cl}_{2}\right]$ and $(\mathrm{b})\left[\mathrm{Cd}\left(\mathrm{H}_{2} \mathrm{BTH}\right) \mathrm{Cl}_{2}\right]$. 


\subsection{Kinetic data.}

Coats-Redfern [30] and Horowitz-Metzger [31] methods have been used to calculate the kinetic parameters associated with thermal degradation. The data are summarized in Table 6 and represented graphically in figure 8.

Table 6. Kinetic Parameters evaluated by Coats-Redfern and Horowitz-Metzger equation for $\mathrm{H}_{2} \mathrm{BTH}$.

\begin{tabular}{|c|c|c|c|c|c|c|c|}
\hline Complex & peak & $\begin{array}{l}\text { Mid Temp } \\
\quad(\mathbf{K})\end{array}$ & $\begin{array}{c}\text { Ea } \\
\mathbf{K J} / \mathbf{m o l}\end{array}$ & $\begin{array}{c}\mathrm{A} \\
(\mathrm{S}-1)\end{array}$ & $\begin{array}{c}\Delta \mathbf{H}^{*} \\
\mathbf{K J} / \mathrm{mol}\end{array}$ & $\begin{array}{c}\Delta \mathbf{S}^{*} \\
\mathbf{K J} / \mathrm{mol} . \mathrm{K}\end{array}$ & $\begin{array}{c}\Delta \mathbf{G}^{*} \\
\mathbf{K J} / \mathbf{m o l}\end{array}$ \\
\hline \multirow{6}{*}[\mathrm{Zn}(\mathrm{H}_{2}\mathrm{BTH})\mathrm{Cl}_{2}]{} & \multirow[t]{2}{*}{1 st } & \multirow[t]{2}{*}{600.55} & 122.27 & $6.21 \mathrm{E}+08$ & 117.27 & -0.0824 & 166.76 \\
\hline & & & 132.26* & $4.84 \mathrm{E}+09 *$ & $127.27 *$ & $-0.0653^{*}$ & $166.51 *$ \\
\hline & \multirow[t]{2}{*}{$2^{\text {nd }}$} & \multirow[t]{2}{*}{757.84} & 133.16 & $8.42 \mathrm{E}+06$ & 126.86 & -0.1201 & 217.87 \\
\hline & & & $146.73 *$ & $7.73 \mathrm{E}+07 *$ & $140.43 *$ & $-0.1017 *$ & $217.47 *$ \\
\hline & \multirow[t]{2}{*}{3 rd } & \multirow[t]{2}{*}{941.48} & 184.22 & $9.73 \mathrm{E}+07$ & 176.40 & -0.1015 & 272.00 \\
\hline & & & $200.67 *$ & $8.44 \mathrm{E}+08^{*}$ & 192.84* & $-0.0836 *$ & 271.54* \\
\hline \multirow{6}{*}[\mathrm{Cd}(\mathrm{H}_{2}\mathrm{BTH})\mathrm{Cl}_{2}]{} & \multirow[t]{2}{*}{$1^{\mathrm{st}}$} & \multirow[t]{2}{*}{579.60} & 121.05 & $9.00 \mathrm{E}+08$ & 116.23 & -0.0790 & 162.03 \\
\hline & & & 130.88* & $7.35 \mathrm{E}+09 *$ & $126.06 *$ & $-0.0616^{*}$ & 161.75* \\
\hline & \multirow[t]{2}{*}{$2^{\text {nd }}$} & \multirow[t]{2}{*}{674.82} & 61.84 & $1.01 \mathrm{E}+04$ & 56.23 & -0.1751 & 174.37 \\
\hline & & & 72.09* & $2.43 \mathrm{E}+03^{*}$ & 66.48* & $-0.1869^{*}$ & 192.59* \\
\hline & \multirow[t]{2}{*}{3 rd } & \multirow[t]{2}{*}{832.30} & 161.66 & $8.33 \mathrm{E}+07$ & 154.74 & -0.1018 & 239.48 \\
\hline & & & 176.41* & $7.45 \mathrm{E}+08 *$ & $169.49 *$ & $-0.0836 *$ & 239.07* \\
\hline
\end{tabular}

The following notices can be drawn:

1. Ea values are high to some extent, indicating that the present chelates possess high thermal stability that can be referred to covalent nature of bonding [32].

2. The values of free energy of activation, $\Delta \mathrm{G}^{*}$ are positive, indicating that the decomposition is a non-spontaneous process and may be due to the oversized structural rigidity of the remaining complex after removing one or more ligand moieties.

3 . The values of $\Delta \mathrm{S}^{*}$; the entropy of activation is negative, clarifying the more ordered activated fragments than the unrecompensed ones and the decomposition stages are slow [33].

4. The positive value of $\Delta \mathrm{H}^{*}$ reveals that thermal decomposition is an endothermic process.

\subsection{Computational studies.}

The DFT molecular modeling structure of $\mathrm{H}_{2} \mathrm{BTH}$ (a) and its $\mathrm{Hg}$ (II) metal complex (b) are illustrated in Figure10, and the data in tables [1S-3S] record the bond lengths and bond angles.

(a)

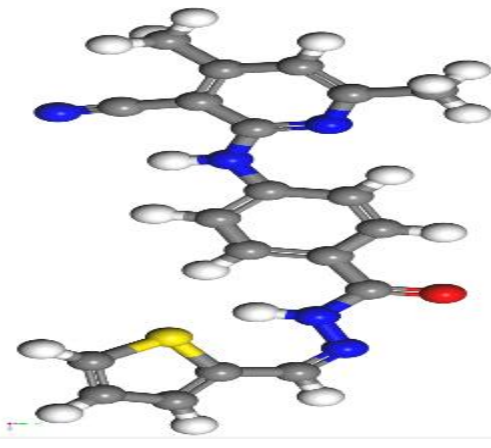

(b)

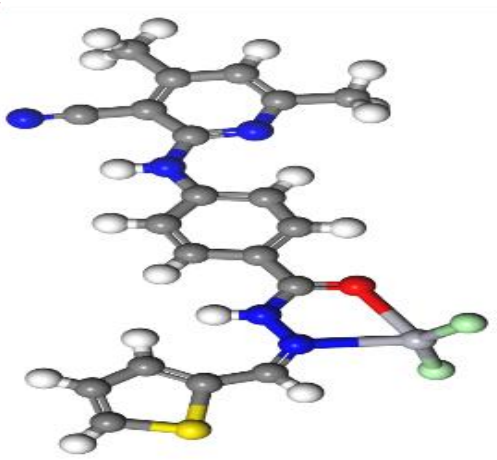

Figure 10. Molecular modeling of (a) $\mathrm{H}_{2} \mathrm{BTH}$; (b) $\left[\mathrm{Hg}\left(\mathrm{H}_{2} \mathrm{BTH}\right) \mathrm{Cl}_{2}\right]$.

1. An insight at the data represented in tables $1 \mathrm{~S}-4 \mathrm{~S}$ (Supplementary Material),It is noticeable the bond angles like $\mathrm{N}(15)-\mathrm{N}(16)-\mathrm{C}(21), \mathrm{N}(15)-\mathrm{C}(14)-\mathrm{O}(17), \mathrm{C}(22)-\mathrm{C}(21)-\mathrm{N}(16)$; $\mathrm{C}(22)-\mathrm{S}(23)-\mathrm{C}(24) ; \mathrm{N}(16)-\mathrm{N}(15)-\mathrm{C}(14)$ and $\mathrm{C}(21)-\mathrm{C}(22)-\mathrm{S}(23)$ are changed on chelation [34]. 
2. The bond lengths enlarged slightly comparable to those in the free ligand upon complexation as $\mathrm{N}(15)-\mathrm{C}(14), \mathrm{N}(16)-\mathrm{C}(21), \mathrm{N}(15)-\mathrm{N}(16)$, and $\mathrm{C}(14)-\mathrm{O}(17)$. The C(14)-O(17) bond distances in the $\mathrm{Zn}$ complex become longer due to forming a new $\mathrm{C}-\mathrm{OH}$ bond. Also, $\mathrm{N}$ (16)-C (21) bond is enlarged as a result of coordination in $\mathrm{Zn}$ (II) and $\mathrm{Hg}$ (II) complexes [34].

\subsubsection{Computed global reactivity descriptors.}

The values of global reactivity descriptors including $\chi$ : electronegativity, $\eta$; global hardness, $\delta$; global softness in addition to FMO's; the Frontier molecular orbitals $\{$ the highest occupied and lowest unoccupied molecular orbitals (HOMO \& LUMO) \} of $\mathrm{H}_{2} \mathrm{BTH}$ (Figure 11) were calculated by B3LYP/6-3111G method and listed in Table 7. The data showed that HOMO is confined overall skeleton though concerning metal complexes, it is restricted on benzene, pyridine rings just as .hydrazone arm $($ Еномо $=-5.055 \mathrm{eV})$ and LUMO is spread over the entire thiophene ring just as hydrazone moiety $\left(\mathrm{ELUMO}_{\mathrm{L}}=-5.18 \mathrm{eV}\right)$ giving energy gap, $\Delta \mathrm{E}$ $=-2.51 \mathrm{eV}$. In Cd (II) complex (Figure $11 \mathrm{f}$ ). HOMO is restricted on pyridine, phenyl rings, and LUMO orbital spread over the planned thiophene Sulfur and hydrazone arm $(\mathrm{EHOMO}=-5.48$ $\mathrm{eV} \& \mathrm{ELUMO}=-3.11 \mathrm{eV}$ ), energy gap $\Delta \mathrm{E}=-2.37 \mathrm{eV}$, lower than that of the ligand. Thus, this complex with a small energy gap could serve as potential materials for harvesting solar radiation in solar cell applications [35]. Moreover, other energetic parameters, including $\chi, \eta$ values of $\mathrm{Cd}^{2+}$ complex, indicate lower softness and reactivity than the hydrazone [36].

(a)

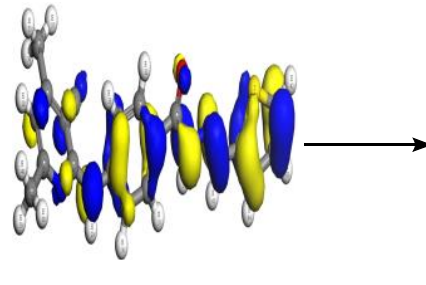

$\mathrm{E}_{\mathrm{HOMO}}=-5.183 \mathrm{eV}$

(c) (b)

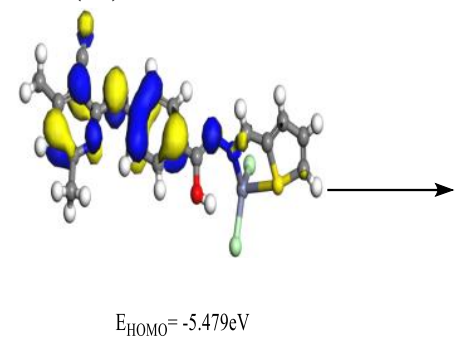

(e)

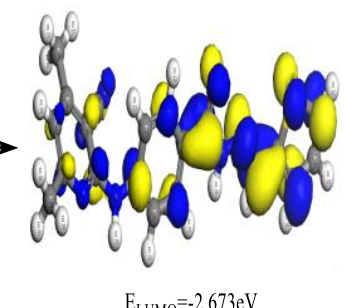

(d)

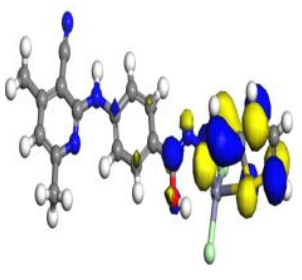

$\mathrm{E}_{\mathrm{LUM0}}=-3.108 \mathrm{eV}$

(f)

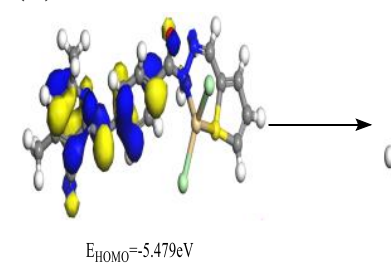

$\mathrm{E}_{\mathrm{HOMO}}=-5.479 \mathrm{eV}$

(g)

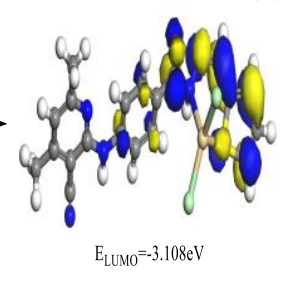

(h)

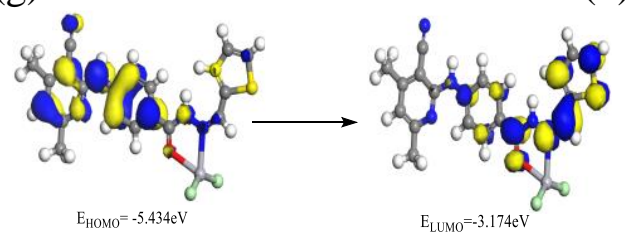

Figure 11. Frontier orbitals (HOMO\& LUMO)(a), (b) of $\mathrm{H}_{2} \mathrm{BTH}$, (c), (d) of $\left[\mathrm{Zn}\left(\mathrm{H}_{2} \mathrm{BTH}\right) \mathrm{Cl}_{2}\right]$; (e), (f) $\left[\mathrm{Cd}\left(\mathrm{H}_{2} \mathrm{BTH}\right) \mathrm{Cl}_{2}\right]$ and $(\mathrm{g})$, (h) $\left[\mathrm{Hg}\left(\mathrm{H}_{2} \mathrm{BTH}\right) \mathrm{Cl}_{2}\right]$. 
Table 7. Calculated $\mathrm{E}_{\mathrm{HOMO}}$, $\mathrm{E}_{\mathrm{LUmO}}$, energy bandgap $\left(E_{\mathrm{H}}-E_{\mathrm{L}}\right)$, chemical potential $(\mu)$, electronegativity $(\chi)$, global hardness $(\eta)$, global softness $(S)$ and global electrophilicity index $(\omega)$ for $\mathrm{H}_{2} \mathrm{BTH}$ and its metal complexes.

\begin{tabular}{c|c|c|c|c|c|c|c|c} 
Compound & $\mathbf{E}_{\boldsymbol{H}} / \mathbf{e V}$ & $\mathbf{E}_{\boldsymbol{L}} / \mathbf{e V}$ & $\mathbf{E}_{\mathbf{H}}-\mathbf{E}_{\mathbf{L}} / \mathbf{e V}$ & $\boldsymbol{\chi} / \mathbf{e V}$ & $\boldsymbol{\mu} / \mathbf{e V}$ & $\boldsymbol{\eta} / \mathbf{e V}$ & $\mathbf{S} / \mathbf{e V}$ & $\boldsymbol{\omega} / \mathbf{e V}$ \\
\hline $\mathrm{H}_{2} \mathrm{BTH}$ & -5.183 & -2.673 & -2.51 & 3.928 & -3.928 & 1.255 & 0.3984 & 6.147 \\
\hline$\left[\mathrm{Zn}\left(\mathrm{H}_{2} \mathrm{BTH}\right) \mathrm{Cl}_{2}\right]$ & -4.293 & -3.451 & -0.842 & 3.872 & -3.872 & 0.421 & 1.188 & 17.806 \\
\hline$\left[\mathrm{Cd}\left(\mathrm{H}_{2} \mathrm{BTH}\right) \mathrm{Cl}_{2}\right]$ & -4.924 & -3.873 & -1.051 & 4.3985 & -4.3985 & 0.5255 & 0.9515 & 18.408 \\
\hline$\left[\mathrm{Hg}\left(\mathrm{H}_{2} \mathrm{BTH}\right) \mathrm{Cl}_{2}\right]$ & -5.217 & -3.028 & -2.189 & 4.123 & -4.123 & 1.095 & 0.457 & 7.762
\end{tabular}

\subsubsection{MEP.}

The molecular electrostatic potential, MEP, represents the plot of electrostatic potential mapped onto the constant electron density surface [37, 38]. The 3D plots of MEP (Figure 12) are drawn, whereas the maximum negative region is expressed by red color, indicating the electrophile attack's available site. The site for attack by a nucleophile is expressed by a blue cool (i.e., the maximum positive region) [39], and the order; red < green < blue is followed. A glance at the MEP of the investigated hydrazone indicates that $\mathrm{N}, \mathrm{O}$, and $\mathrm{S}$ atoms have negative potential while $\mathrm{H}$ atoms assign positive potential.

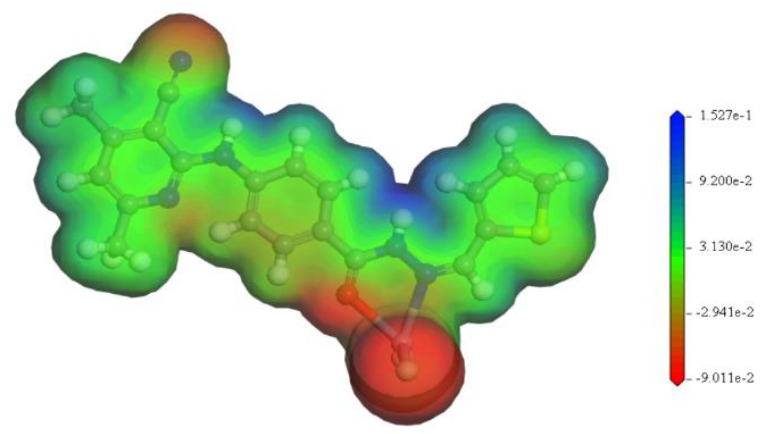

Figure 12. MEP map for $\left[\mathrm{Hg}\left(\mathrm{H}_{2} \mathrm{BTH}\right) \mathrm{Cl}_{2}\right]$.

\subsection{Antimicrobial activity.}

Table 8 indicates the antimicrobial activity (antibacterial and antifungal) expressed in terms of inhibition diameter $(\mathrm{mm})$ obtained for both the hydrazone and its divalent metal complexes. The data included reveals that zinc complex exhibited the significant potent activity $(73.1 \%, 75.0 \%)$ and $85.2 \%$ against the bacterial (E.coli; S. aureus) and fungus (Cand.alb), followed by zinc complex with activity index $(50.0 \%, 62.5 .0 \%)$ and $51.8 \%$ against the bacterial (E.coli; S. aureus) and fungus (Cand.ab).The hydrazone did not show any response and mercury complex, although its known toxicity exhibited weak inhibition ability comparable with other complexes.

Table 8. Biological activity studies for $\mathrm{H}_{2}$ BTHand its complexes.

\begin{tabular}{|c|c|c|c|c|c|c|c|}
\hline \multirow{2}{*}{ No. } & Compound & $\begin{array}{c}\text { Eiameter of } \\
\text { inhibition zone } \\
(\mathrm{mm})\end{array}$ & $\begin{array}{c}\% \text { Activity } \\
\text { index }\end{array}$ & $\begin{array}{c}\text { Diameter of } \\
\text { inhibition zone } \\
(\mathrm{mm})\end{array}$ & $\begin{array}{c}\text { \% Activity } \\
\text { index }\end{array}$ & $\begin{array}{c}\text { Diameter of } \\
\text { inhibition zone } \\
(\mathrm{mm})\end{array}$ & $\begin{array}{c}\text { \% Activity } \\
\text { index }\end{array}$ \\
\hline 1 & $\mathrm{H}_{2} \mathrm{BTH}$ & - & --- & - & --- & - & --- \\
\hline 2 & {$\left[\mathrm{Zn}\left(\mathrm{H}_{2} \mathrm{BTH}\right) \mathrm{Cl}_{2}\right]$} & 13 & 50.0 & 15 & 62.5 & 14 & 51.8 \\
\hline 3 & {$\left[\mathrm{Cd}\left(\mathrm{H}_{2} \mathrm{BTH}\right) \mathrm{Cl}_{2}\right]$} & 19 & 73.1 & 18 & 75.0 & 23 & 85.2 \\
\hline 4 & {$\left[\mathrm{Hg}\left(\mathrm{H}_{2} \mathrm{BTH}\right) \mathrm{Cl}_{2}\right]$} & 4 & 15.4 & 5 & 20.8 & 2 & 7.4 \\
\hline \multicolumn{2}{|c|}{ Ampicillin* } & 26 & 100 & 24 & 100 & $\mathrm{NA}$ & ---- \\
\hline \multicolumn{2}{|c|}{ Clotrimazole* } & - & ---- & - & ---- & 27 & 100 \\
\hline
\end{tabular}

The enhancement of antibacterial activity on complex formation is well documented by Overtone' theory and chelation hypothesis. As the chelation facilitates the penetration through into the lipid membrane and blocks the metal-binding sites on the enzymes of the 
microorganism and the presence of groups such as $\mathrm{OH}$ group in zinc complex and the free carbonyl group in cadmium complex increased the permeability process into the organism under test.

\subsection{DNA binding.}

The UV-Vis absorption spectra of studied complexes were performed in the absence and the presence of CT-DNA (Figure 13). In the presence of DNA, the bands that appear at $337 \mathrm{~nm}$ for $\mathrm{Zn}$ and $\mathrm{Cd}$ complexes and $339 \mathrm{~nm}$ for $\mathrm{Hg}$ complex; showed significant hypochromic shift. The binding constant $(\mathrm{kb})$ values were: $2.53 \times 10^{6}, 2.58 \times 10^{6}$, and 5.10 $\mathrm{x} 10^{6}$ for $\left[\mathrm{Zn}\left(\mathrm{H}_{2} \mathrm{BTH}\right) \mathrm{Cl}_{2}\right],\left[\mathrm{Cd}\left(\mathrm{H}_{2} \mathrm{BTH}\right) \mathrm{Cl}_{2}\right]$ and $\left[\mathrm{Hg}\left(\mathrm{H}_{2} \mathrm{BTH}\right) \mathrm{Cl}_{2}\right]$, respectively revealing that the binding with DNA is mainly due to the intercalation mode and the complexes are strong intercalator. It is clear that the $\mathrm{Hg}$ complex especially had the highest $\mathrm{K}_{\mathrm{b}}$ and the strongest ability to bind DNA.
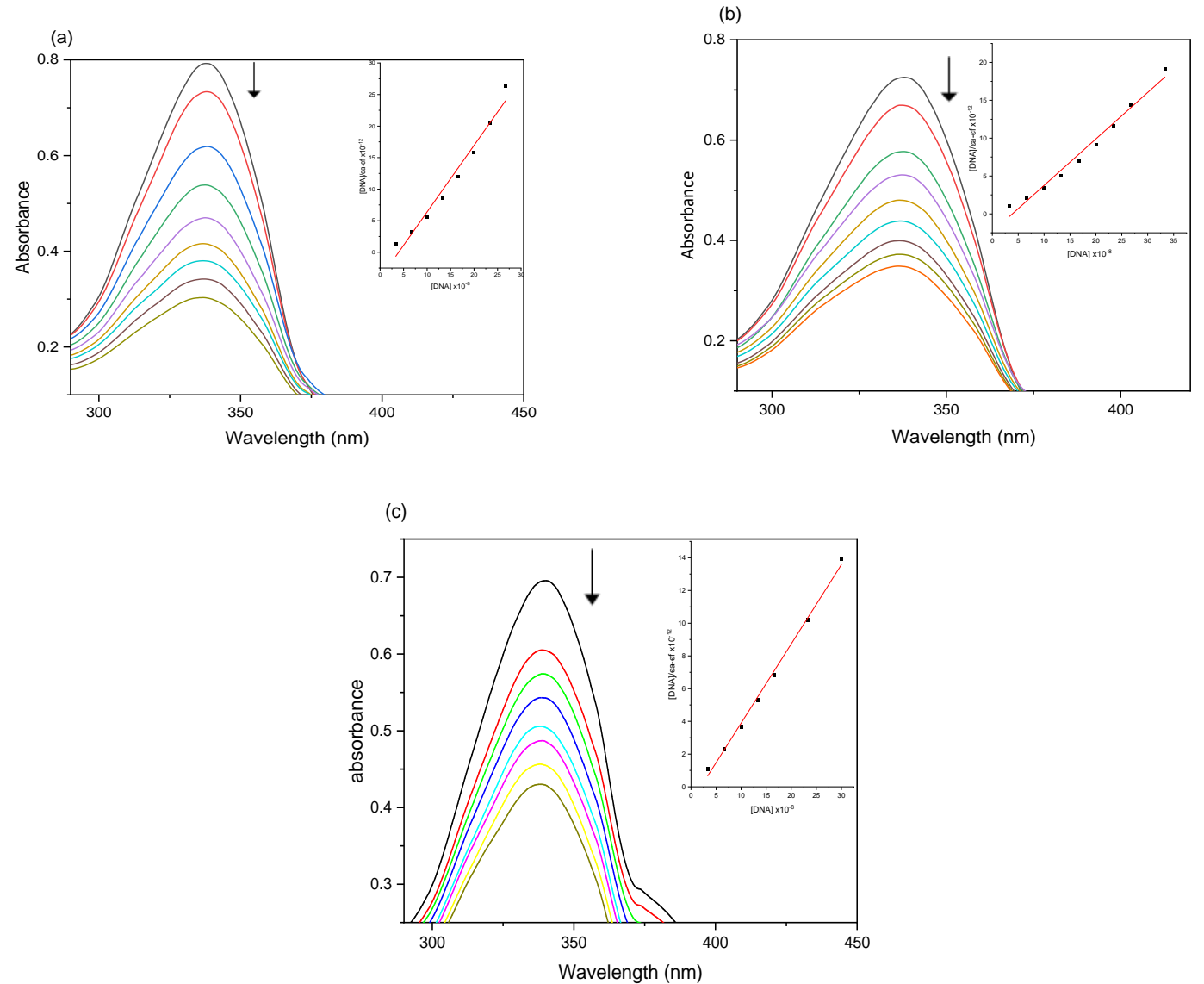

Figure 13. The electronic spectra of (a) $\left[\mathrm{Zn}\left(\mathrm{H}_{2} \mathrm{BTH}\right) \mathrm{Cl}_{2}\right]$; (b) $\left[\mathrm{Cd}\left(\mathrm{H}_{2} \mathrm{BTH}\right) \mathrm{Cl}_{2}\right]$; (c) $\left[\mathrm{Hg}\left(\mathrm{H}_{2} \mathrm{BTH}\right) \mathrm{Cl}_{2}\right]$ with and without CT-DNA; the arrow indicates the absorbance changes on increasing CT-DNA concentration.

\section{Conclusions}

The ligand 4-((3-cyano-4,6-dimethylpyridin-2-yl)amino) benzohydrazide $\left(\mathrm{H}_{2} \mathrm{BTH}\right)$ and its metal complexes $\left(\mathrm{Zn}^{2+}, \mathrm{Cd}^{2+}\right.$ and $\left.\mathrm{Hg}^{2+}\right)$ were formed and characterized with different techniques; elemental analyses and spectral method. IR data showed that the $\mathrm{H}_{2} \mathrm{BTH}$ ligand acts as neutral NS or NO bidentate, and the complexes obeyed the molecular formula[ $\left.\mathrm{Zn}\left(\mathrm{H}_{2} \mathrm{BTH}\right) \mathrm{Cl}_{2}\right]$, [Cd( $\left.\left.\mathrm{H}_{2} \mathrm{BTH}\right) \mathrm{Cl}_{2}\right]$, and $\left[\mathrm{Hg}\left(\mathrm{H}_{2} \mathrm{BTH}\right) \mathrm{Cl}_{2}\right]$, respectively. A tetrahedral environment was proposed for $\mathrm{Zn}^{3+}, \mathrm{Cd}^{2+}$, and $\mathrm{Hg}^{2+}$ complexes. The significance of the present assay lies in the prevalence of new compounds that might have a large effect when applied as drugs against bacteria and cancer diseases as these compounds showed great results as 
intercalate materials when binding with CT-DNA. In other words, the title compounds could be helpful in the therapeutic uses.

\section{Funding}

This research received no external funding.

\section{Acknowledgments}

The first author gratefully acknowledges the Microbiology Unit at the Faculty of Pharmacy, Mansoura University, for carrying out the biological activity experimental work.

\section{Conflicts of Interest}

The authors declare no conflict of interest.

\section{References}

1. Hathaway, B.J.; Wilkinson, G.; Gillard, R.D.; McCleverty, J.A. Comprehensive coordination chemistry. The synthesis, reactions, properties and applications of coordination compounds 1987, 5, 533-774.

2. Dikmen, G.; Ünver, H. A new Pd(II)-Hydrazide-Triphenylphosphine complex: Synthesis, crystal structure, spectroscopic characterization and theoretical calculations. J. Mol. Struct. 2021, 1225, 129139, https://doi.org/10.1016/j.molstruc.2020.129139.

3. Pocrnić, M.; Kontrec, D.; Miljanić, S.; Soldin, Ž.; Budimir, A.; Galić, N. Gallium(III) complexes of aroylhydrazones derived from nicotinic acid hydrazide in solid state and in solution. J. Mol. Struct. 2021, 1227, 129564, https://doi.org/10.1016/j.molstruc.2020.129564.

4. Chakraborty, J.; Samanta, B.; Pilet, G.; Mitra, S. Synthesis, structure and spectral characterisation of a hydrogen-bonded polymeric manganese(III) Schiff base complex. Struct. Chem. 2006, 17, 585-593, https://doi.org/10.1007/s11224-006-9076-3.

5. Shrivastav, A.; Singh, N.K.; Tripathi, P.; George, T.; Dimmock, J.R.; Sharma, R.K. Copper(II) and manganese(III) complexes of $\mathrm{N}^{\prime}$-[(2-hydroxy phenyl) carbonothioyl] pyridine-2-carbohydrazide: novel therapeutic agents for cancer. Biochimie 2006, 88, 1209-1216, https://doi.org/10.1016/j.biochi.2006.03.004.

6. Ramya Rajan, M.P.; Rathikha, R.; Nithyabalaji, R.; Sribalan, R. Synthesis, characterization, in silico studies and in vitro biological evaluation of isoniazid-hydrazone complexes. J. Mol. Struct. 2020, 1216, 128297, https://doi.org/10.1016/j.molstruc.2020.128297.

7. Cristau, H.-J.; Cellier, Pascal P.; Spindler, J.-F.; Taillefer, M. Mild Conditions for Copper-Catalysed NArylation of Pyrazoles. Eur. J. Org. Chem. 2004, 2004, 695-709, https://doi.org/10.1002/ejoc.200300709.

8. Sousa, G.F.d.; Mangas, M.B.P.; Francisco, R.H.P.; Gambardella, M.T.d.P.; Rodrigues, A.M.G.D.; Abras, A. New Heptacoordinated Organotin (IV) Complexes Derivatives of 2, 6-diacetylpyridinebis (2furanoylhydrazone), H2dapf, and 2, 6-diacetylpyridinebis (2-thenoylhydrazone), H2dapt: Crystal and Molecular Structure of [Me2Sn (Hdapt] Br. H2O. J. Braz. Chem. Soc. 1999, 10, 222-230.

9. Bacchi, A.; Pelizzi, G.; Jeremić, D.; Sladić, D.; Gruden-Pavlović, M.; Andjelković, K. Synthesis and structural characterization of copper(II) complexes with the 2'-[1-(2-pyridinyl)ethylidene]oxalohydrazide ligand. Transition Met. Chem. 2003, 28, 935-938, https://doi.org/10.1023/A:1026316611296.

10. Pelizzi, C.; Pelizzi, G.; Predieri, G. Investigation into aroylhydrazones as chelating agents: V. Synthesis and structural characterization of two seven-coordinate organotin(IV) complexes with 2,6-diacetylpyridine bis(2aminobenzoylhydrazone). J. Organomet. Chem. 1984, 263, 9-20, https://doi.org/10.1016/0022328X(84)85005-6.

11. El-Gammal, O.A.; Fouda A.A.; Nabih, D.M. Synthesis, spectral characterization, DFT and in vitro antibacterial activity of $\mathrm{Zn}(\mathrm{II}), \mathrm{Cd}(\mathrm{II})$ and $\mathrm{Hg}(\mathrm{II})$ complexes derived from a new thiosemicarbazide. Letters in Applied NanoBioScience 2019, 8, 715-722, https://doi.org/10.33263/LIANBS84.715722.

12. El-Gammal, O.A.; Abu El-Reash, G.M.; Goama, H.E. Mononuclear $\mathrm{Cr}(\mathrm{III}), \mathrm{Mn}$ (II), and Fe(III) complexes derived from new ONO symmetrical flexible hydrazone: synthesis, spectral characterization, optical band gap and DFT computational study. Letters in Applied NanoBioScience 2019, 8, 743-753, https://doi.org/10.33263/LIANBS84.743753.

13. Vogel, A.I. Text-book of quantitative inorganic analysis including elementary instrumental analysis. 1961.

14. Geary, W.J. The use of conductivity measurements in organic solvents for the characterisation of coordination compounds. Coord. Chem. Rev. 1971, 7, 81-122, https://doi.org/10.1016/S0010-8545(00)80009-0. 
15. Modeling and Simulation Solutions for Chemicals and Materials Research. Materials Studio, Version 7.0, Accelryssoftware Inc., San Diego, USA, 2011.

16. Hammer, B.; Hansen, L.B.; Nørskov, J.K. Improved adsorption energetics within density-functional theory using revised Perdew-Burke-Ernzerhof functionals. Physical review B 1999, 59, 7413, http://link.aps.org/doi/10.1103/PhysRevB.59.7413.

17. Delley, B. From molecules to solids with the DMol3 approach. The Journal of Chemical Physics 2000, 113, 7756-7764, https://doi.org/10.1063/1.1316015.

18. Stylianakis, I.; Kolocouris, A.; Kolocouris, N.; Fytas, G.; Foscolos, G.B.; Padalko, E.; Neyts, J.; De Clercq, E. Spiro[pyrrolidine-2,2'-adamantanes]: synthesis, anti-influenza virus activity and conformational properties. Bioorg. Med. Chem. Lett. 2003, 13, 1699-1703, https://doi.org/10.1016/s0960-894x(03)00231-2.

19. Yang, P.; Zhang, L.-L.; Wang, Z.-Z.; Zhang, D.-D.; Liu, Y.-M.; Shi, Q.-S.; Xie, X.-B. Nickel complexes of aroylhydrazone ligand: synthesis, crystal structure and DNA binding properties. J. Inorg. Biochem. 2020, 203, 110919, https://doi.org/10.1016/j.jinorgbio.2019.110919.

20. El-Gammal, O.A.; El-Reash, G.A.; Ahmed, S.F. Structural, spectral, thermal and biological studies on 2-oxoN'-((4-oxo-4H-chromen-3-yl)methylene)-2-(phenylamino)acetohydrazide (H2L) and its metal complexes. $J$. Mol. Struct. 2012, 1007, 1-10, https://doi.org/10.1016/j.molstruc.2011.03.043.

21. El-Gammal, O.A.; Abu El-Reash, G.M.; Ghazy, S.E.; Radwan, A.H. Synthesis, characterization, molecular modeling and antioxidant activity of (1E,5E)-1,5-bis(1-(pyridin-2-yl)ethylidene)carbonohydrazide (H2APC) and its zinc(II), cadmium(II) and mercury(II) complexes. J. Mol. Struct. 2012, 1020, 6-15, https://doi.org/10.1016/j.molstruc.2012.04.029.

22. El-Asmy, A.A.; El-Gammal, O.A.; Radwan, H.A.; Ghazy, S.E. Ligational, analytical and biological applications on oxalyl bis(3,4-dihydroxybenzylidene) hydrazone. Spectrochimica Acta Part A: Molecular and Biomolecular Spectroscopy 2010, 77, 297-303, https://doi.org/10.1016/j.saa.2010.05.026.

23. Manimohan, M.; Pugalmani, S.; Sithique, M.A. Synthesis, Spectral Characterisation and Biological Activities of Novel Biomaterial/N, N, O Donor Tridentate Co (II), Ni (II) and Zn (II) Complexes of Hydrazide Based Biopolymer Schiff Base Ligand. Journal of Inorganic and Organometallic Polymers and Materials 2020, 30, 4481-4495, https://doi.org/10.1007/s10904-020-01578-7.

24. El-Gammal, O.A.; Rakha, T.H.; Metwally, H.M.; Abu El-Reash, G.M. Synthesis, characterization, DFT and biological studies of isatinpicolinohydrazone and its $\mathrm{Zn}(\mathrm{II}), \mathrm{Cd}(\mathrm{II})$ and $\mathrm{Hg}(\mathrm{II})$ complexes. Spectrochimica Acta Part A: Molecular and Biomolecular Spectroscopy 2014, 127, 144-156, https://doi.org/10.1016/j.saa.2014.02.008.

25. El-Gammal, O.A. Mononuclear and binuclear complexes derived from hydrazone Schiff base NON donor ligand: Synthesis, structure, theoretical and biological studies. Inorg. Chim. Acta 2015, 435, 73-81, https://doi.org/10.1016/j.ica.2015.06.009.

26. Vinoth, G.; Indira, S.; Bharathi, M.; Alves, L.G.; Martins, A.M.; Shanmuga Bharathi, K. Cyanosilylation of

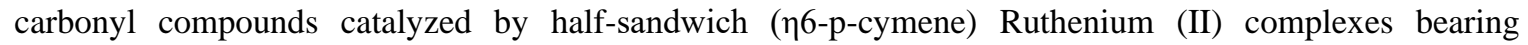
heterocyclic hydrazone derivatives. Inorg. Chim. Acta 2021, 514, 120006, https://doi.org/10.1016/j.ica.2020.120006.

27. Okagu, O.D.; Ugwu, K.C.; Ibeji, C.U.; Ekennia, A.C.; Okpareke, O.C.; Ezeorah, C.J.; Anarado, C.J.O.; Babahan, I.; Coban, B.; Yıldız, U.; Cömert, F.; Ujam, O.T. Synthesis and characterization of Cu(II), Co(II) and Ni(II) complexes of a benzohydrazone derivative: Spectroscopic, DFT, antipathogenic and DNA binding studies. J. Mol. Struct. 2019, 1183, 107-117, https://doi.org/10.1016/j.molstruc.2019.01.069.

28. Bhale, S.; Gore, V.; Tekale, S., Pawar, R. P. Synthesis, Characterization and Antimicrobial Activity of Ni(II), $\mathrm{Zn}(\mathrm{II})$, and $\mathrm{Cd}(\mathrm{II})$ Complexes of 3/4-Bromo-Benzoic Acid (Phenyl-Pyridine-2-yl-Methylene)-Hydrazide Ligand, Letters in Applied NanoBioscience $\mathbf{2 0 2 0}$ 4, 1529-1537, https://doi.org/10.33263/LIANBS94.15291537.

29. Castiñeiras, A.; Gomez, M.C.; Hiller, W. Structure of tetrakis (N, N-dimethylbenzenecarbothioamide-S) cadmium (II) diperchlorate monohydrate. Acta Crystallogr. Sect. C: Cryst. Struct. Commun. 1992, 48, 22152218, https://doi.org/10.1107/S0108270192004359.

30. Sawada, T.; Fukumaru, K.; Sakurai, H. L-Band ESR Spectra of Copper(II) Complexes with CuN4 Configurations. Biochem. Biophys. Res. Commun. 1995, 216, 154-161, https://doi.org/10.1006/bbrc.1995.2604.

31. Shimizu, I.; Morimoto, Y.; Faltermeier, D.; Kerscher, M.; Paria, S.; Abe, T.; Sugimoto, H.; Fujieda, N.; Asano, K.; Suzuki, T.; Comba, P.; Itoh, S. Tetrahedral Copper(II) Complexes with a Labile Coordination Site Supported by a Tris-tetramethylguanidinato Ligand. Inorg. Chem. 2017, 56, 9634-9645, https://doi.org/10.1021/acs.inorgchem.7b01154.

32. Al-Hazmi, G.A.A.; Abou-Melha, K.S.; El-Metwaly, N.M.; Althagafi, I.; Shaaban, F.; Elghalban, M.G.; ElGamil, M.M. Spectroscopic and theoretical studies on $\mathrm{Cr}$ (III), Mn (II) and Cu (II) complexes of hydrazone 
derived from picolinic hydrazide and O-vanillin and evaluation of biological potency. Appl. Organomet. Chem. 2020, 34, e5408, https://doi.org/10.1002/aoc.5408.

33. Maravalli, P.B.; Gudasi, K.B.; Goudar, T.R. Thermal studies of cobalt(II), nickel(II) and copper(II) 3substituted-4-salicylideneamino-5-mercapto-1,2,4-triazole complexes. Transition Met. Chem. 2000, 25, 411, https://doi.org/10.1023/A:1007032902220.

34. Katouah, H.; Sayqal, A.; Al-Solimy, A.M.; Abumelha, H.M.; Shah, R.; Alkhatib, F.; Alzahrani, S.; Zaky, R.; El-Metwaly, N.M. Facile synthesis and deliberate characterization for new hydrazide complexes; cyclic voltammetry, crystal packing, eukaryotic DNA degradation and in-silico studies. J. Mol. Liq. 2020, 320, 114380, https://doi.org/10.1016/j.molliq.2020.114380.

35. El-Gammal, O.A.; Bekheit, M.M.; El-Brashy, S.A. Synthesis, characterization and in vitro antimicrobial studies of $\mathrm{Co}(\mathrm{II}), \mathrm{Ni}(\mathrm{II})$ and $\mathrm{Cu}(\mathrm{II})$ complexes derived from macrocyclic compartmental ligand. Spectrochimica Acta Part A: Molecular and Biomolecular Spectroscopy 2015, 137, 207-219, https://doi.org/10.1016/j.saa.2014.08.016.

36. Noorussabah, N.; Choudhary, M.; Das, N.; Mohan, B.; Singh, K.; Singh, R.K.; Ahmad, K.; Muhammad, S.; Kumar, S. Copper(II) and Nickel(II) Complexes of Tridentate Hydrazide and Schiff Base Ligands Containing Phenyl and Naphthalyl Groups: Synthesis, Structural, Molecular Docking and Density Functional Study. Journal of Inorganic and Organometallic Polymers and Materials 2020, 30, 4426-4440, https://doi.org/10.1007/s10904-020-01610-w.

37. Fukui, K.; Yonezawa, T.; Nagata, C.; Shingu, H. Molecular Orbital Theory of Orientation in Aromatic, Heteroaromatic, and Other Conjugated Molecules. In Frontier Orbitals and Reaction Paths, World Scientific 1997, 7, 33-42, https://doi.org/10.1142/9789812795847_0002.

38. Luque, F.J.; López, J.M.; Orozco, M. Perspective on "Electrostatic interactions of a solute with a continuum. A direct utilization of ab initio molecular potentials for the prevision of solvent effects". Theor. Chem. Acc. 2000, 103, 343-345, https://doi.org/10.1007/s002149900013.

39. Politzer, P.; Laurence, P.R.; Jayasuriya, K. Molecular electrostatic potentials: an effective tool for the elucidation of biochemical phenomena. Environ. Health Perspect. 1985, 61, 191-202, https://doi.org/10.1289/ehp.8561191. 


\section{Supplementary Materials}

Table 1S. Bond lengths $(\AA)$ of $\mathrm{H}_{2} \mathrm{BTH}$ and its metal complexes.

\begin{tabular}{c|c|c|c|c}
\hline $\begin{array}{c}\text { Compounds } \\
\text { Bonds }\end{array}$ & $\mathbf{H}_{2} \mathbf{B} \mathbf{T H}$ & {$\left[\mathbf{Z n}\left(\mathbf{H}_{2} \mathbf{B} \mathbf{T H}\right) \mathbf{C l}_{2}\right]$} & {$\left[\mathbf{C d}\left(\mathbf{H}_{2} \mathbf{B} \mathbf{T H}\right) \mathbf{C l}_{2}\right]$} & {$\left[\mathbf{H g}\left(\mathbf{H}_{2} \mathbf{B T H}\right) \mathbf{C l}_{2}\right]$} \\
\hline $\mathrm{N}(15)-\mathrm{N}(16)$ & 1.353 & 1.438 & 1.472 & 1.394 \\
\hline $\mathrm{N}(15)-\mathrm{C}(14)$ & 1.372 & 1.323 & 1.460 & 1.398 \\
\hline $\mathrm{C}(14)-\mathrm{O}(17)$ & 1.21 & 1.393 & 1.263 & 1.287 \\
\hline $\mathrm{N}(15)-\mathrm{H}$ & 1.007 & ------ & 1.030 & 1.020 \\
\hline $\mathrm{N}(16)-\mathrm{C}(21)$ & 1.266 & 1.331 & 1.317 & 1.325 \\
\hline $\mathrm{C}(21)-\mathrm{H}(39)$ & 1.107 & 1.091 & 1.096 & 1.091 \\
\hline $\mathrm{C}(22)-\mathrm{S}(23)$ & 1.473 & 1.835 & 1.843 & 1.848 \\
\hline $\mathrm{C}(24)-\mathrm{S}(23)$ & 1.464 & 1.814 & 1.813 & 1.793 \\
\hline $\mathrm{C}(21)-\mathrm{C}(22)$ & 1.346 & 1.431 & 1.440 & 1.445 \\
\hline $\mathrm{M}-\mathrm{N}(16)$ & ----- & 2.097 & ---- & 2.571 \\
\hline $\mathrm{M}-\mathrm{N}(15)$ & ----- & ----- & 2.736 & ---- \\
\hline $\mathrm{M}-\mathrm{O}(17)$ & ----- & ----- & ---- & 2.520 \\
\hline $\mathrm{M}-\mathrm{S}(23)$ & ----- & 2.856 & 3.034 & ----
\end{tabular}

Table 2S. Selected angles $\left({ }^{\circ}\right)$ of $_{2} \mathrm{BTH}$ and $\left[\mathrm{Zn}\left(\mathrm{H}_{2} \mathrm{BTH}\right) \mathrm{Cl}_{2}\right]$.

\begin{tabular}{c|c|c|c}
\multicolumn{2}{c|}{$\mathbf{H}_{2} \mathbf{B}$ TH } & \multicolumn{2}{c}{$\left[\mathbf{Z n}\left(\mathbf{H}_{2} \mathbf{B T H}\right) \mathbf{C l}_{2}\right]$} \\
\hline Angle & Degree $^{\circ}{ }^{\circ}$ & Angle & Degree $^{\circ}$ ) \\
\hline $\mathrm{C}(24)-\mathrm{S}(23)-\mathrm{C}(22)$ & 97.966 & $\mathrm{C}(24)-\mathrm{S}(23)-\mathrm{C}(22)$ & 89.382 \\
\hline $\mathrm{S}(23)-\mathrm{C}(22)-\mathrm{C}(21)$ & 126.175 & $\mathrm{~S}(23)-\mathrm{C}(22)-\mathrm{C}(21)$ & 122.299 \\
\hline $\mathrm{C}(22)-\mathrm{C}(21)-\mathrm{N}(16)$ & 131.319 & $\mathrm{C}(22)-\mathrm{C}(21)-\mathrm{N}(16)$ & 123.914 \\
\hline $\mathrm{C}(21)-\mathrm{N}(16)-\mathrm{N}(15)$ & 122.636 & $\mathrm{C}(21)-\mathrm{N}(16)-\mathrm{N}(15)$ & 114.349 \\
\hline $\mathrm{N}(16)-\mathrm{N}(15)-\mathrm{C}(14)$ & 123.432 & $\mathrm{~N}(16)-\mathrm{N}(15)-\mathrm{C}(14)$ & 117.848 \\
\hline $\mathrm{O}(17)-\mathrm{C}(14)-\mathrm{N}(15)$ & 119.914 & $\mathrm{O}(17)-\mathrm{C}(14)-\mathrm{N}(15)$ & 126.544 \\
\hline & & $\mathrm{Cl}(46)-\mathrm{Zn}(44)-\mathrm{Cl}(45)$ & 127.558 \\
\hline & & $\mathrm{Cl}(46)-\mathrm{Zn}(44)-\mathrm{S}(23)$ & 95.401 \\
\hline & & $\mathrm{Cl}(46)-\mathrm{Zn}(44)-\mathrm{N}(16)$ & 115.755 \\
\hline & & $\mathrm{Cl}(45)-\mathrm{Zn}(44)-\mathrm{S}(23)$ & 110.600 \\
\hline & & $\mathrm{Cl}(45)-\mathrm{Zn}(44)-\mathrm{N}(16)$ & 113.645 \\
\hline & & $\mathrm{S}(23)-\mathrm{Zn}(44)-\mathrm{N}(16)$ & 78.576
\end{tabular}

Table 3S. Selected angles $\left(^{\circ}\right)$ of $\left[\mathrm{Cd}\left(\mathrm{H}_{2} \mathrm{BTH}\right) \mathrm{Cl}_{2}\right]$ and $\left[\mathrm{Hg}\left(\mathrm{H}_{2} \mathrm{BTH}\right) \mathrm{Cl}_{2}\right]$.

[Cd $\left(\mathrm{H}_{2} \mathrm{BTH}\right) \mathrm{Cl}_{2}$ ]

\begin{tabular}{c|c|c|c}
\multicolumn{2}{c}{$\left[\mathbf{C d}\left(\mathbf{H}_{2} \mathbf{B} \mathbf{T H}\right) \mathbf{C l}_{2}\right]$} & \multicolumn{2}{c}{$\left[\mathbf{H g}\left(\mathbf{H}_{2} \mathbf{B T H}\right) \mathbf{C l}_{2}\right]$} \\
\hline Angle & Degree $\left({ }^{\circ}\right)$ & Angle & Degree $\left({ }^{\circ}\right)$ \\
\hline $\mathrm{Cl}(46)-\mathrm{Cd}(44)-\mathrm{Cl}(45)$ & 141.396 & $\mathrm{Cl}(46)-\mathrm{Hg}(44)-\mathrm{Cl}(45)$ & 144.059 \\
\hline $\mathrm{Cl}(46)-\mathrm{Cd}(44)-\mathrm{S}(23)$ & 90.656 & $\mathrm{Cl}(46)-\mathrm{Hg}(44)-\mathrm{O}(17)$ & 103.167 \\
\hline $\mathrm{Cl}(46)-\mathrm{Cd}(44)-\mathrm{N}(15)$ & 107.914 & $\mathrm{Cl}(46)-\mathrm{Hg}(44)-\mathrm{N}(16)$ & 110.253 \\
\hline $\mathrm{Cl}(45)-\mathrm{Cd}(44)-\mathrm{S}(23)$ & 117.915 & $\mathrm{Cl}(45)-\mathrm{Hg}(44)-\mathrm{O}(17)$ & 103.824 \\
\hline $\mathrm{Cl}(45)-\mathrm{Cd}(44)-\mathrm{N}(15)$ & 107.142 & $\mathrm{Cl}(45)-\mathrm{Hg}(44)-\mathrm{N}(16)$ & 102.458 \\
\hline $\mathrm{S}(23)-\mathrm{Cd}(44)-\mathrm{N}(15)$ & 66.809 & $\mathrm{O}(17)-\mathrm{Hg}(44)-\mathrm{N}(16)$ & 65.055 \\
\hline $\mathrm{C}(24)-\mathrm{S}(23)-\mathrm{C}(22)$ & 89.610 & $\mathrm{C}(24)-\mathrm{S}(23)-\mathrm{C}(22)$ & 89.795 \\
\hline $\mathrm{S}(23)-\mathrm{C}(22)-\mathrm{C}(21)$ & 125.275 & $\mathrm{~S}(23)-\mathrm{C}(22)-\mathrm{C}(21)$ & 115.299 \\
\hline $\mathrm{C}(22)-\mathrm{C}(21)-\mathrm{N}(16)$ & 135.535 & $\mathrm{C}(22)-\mathrm{C}(21)-\mathrm{N}(16)$ & 133.751 \\
\hline $\mathrm{C}(21)-\mathrm{N}(16)-\mathrm{N}(15)$ & 119.651 & $\mathrm{C}(21)-\mathrm{N}(16)-\mathrm{N}(15)$ & 123.491 \\
\hline $\mathrm{N}(16)-\mathrm{N}(15)-\mathrm{C}(14)$ & 109.961 & $\mathrm{~N}(16)-\mathrm{N}(15)-\mathrm{C}(14)$ & 119.285 \\
\hline $\mathrm{O}(17)-\mathrm{C}(14)-\mathrm{N}(15)$ & 117.500 & $\mathrm{O}(17)-\mathrm{C}(14)-\mathrm{N}(15)$ & 120.590
\end{tabular}

